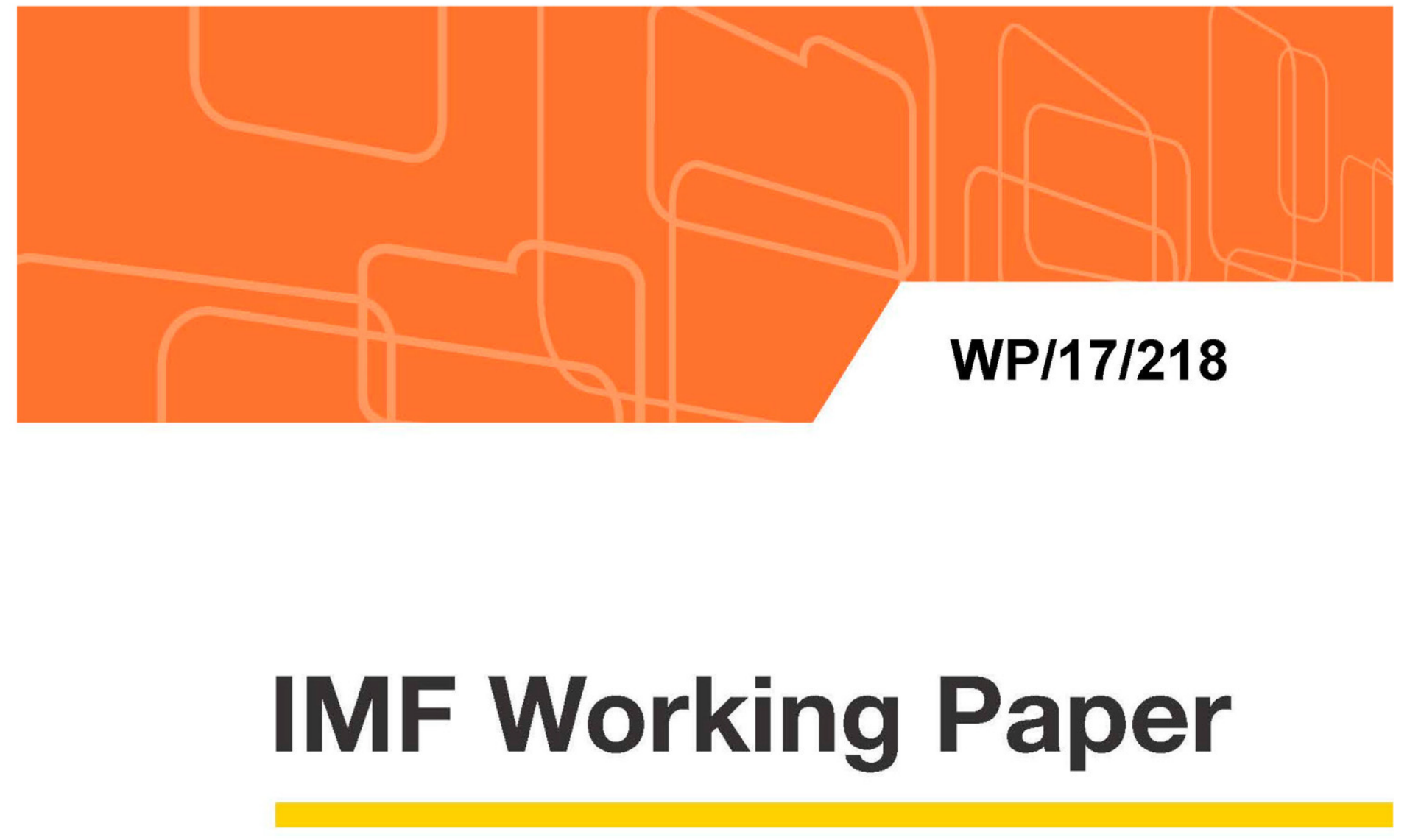

\title{
How Financial Conditions Matter Differently across Latin America
}

By Luis Brandao Marques and Esther Pérez Ruiz

IMF Working Papers describe research in progress by the author(s) and are published to elicit comments and to encourage debate. The views expressed in IMF Working Papers are those of the author(s) and do not necessarily represent the views of the IMF, its Executive Board, or IMF management.

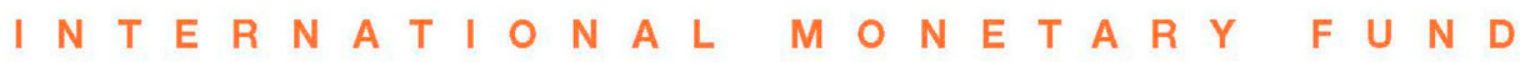




\section{WP/17/218}

\section{IMF Working Paper}

\section{How Financial Conditions Matter Differently across Latin America}

By Luis Brandao Marques and Esther Pérez Ruiz

IMF Working Papers describe research in progress by the author(s) and are published to elicit comments and to encourage debate. The views expressed in IMF Working Papers are those of the author(s) and do not necessarily represent the views of the IMF, its Executive Board, or IMF management.

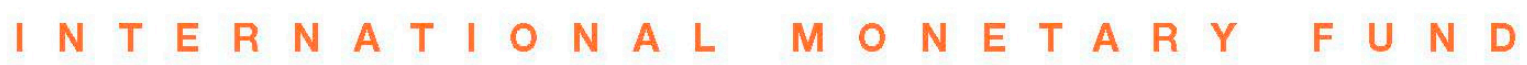




\title{
IMF Working Paper
}

Western Hemisphere Department

\section{How Financial Conditions Matter Differently across Latin America Prepared by Luis Brandao Marques and Esther Pérez Ruiz}

Authorized for distribution by Stephan Danninger

October 2017

\author{
This Working Paper should not be reported as representing the views of the IMF. \\ The views expressed in this Working Paper are those of the author(s) and do not necessarily represent \\ those of the IMF or IMF policy. Working Papers describe research in progress by the author(s) and are \\ published to elicit comments and to further debate.
}

\begin{abstract}
This paper develops comparable financial conditions indices (FCIs) for the six large and most financially-integrated Latin American economies (LA6) by following Korobilis (2013) and Koop and Korobilis (2014). The main findings are as follows. First, the estimated FCIs are influenced by a commodity cycle, a global financial cycle, as well as country-specific episodes of financial distress. Second, by early 2017, financial conditions remained favorable in most LA6 economies relative to historical standards. Third, the impact of financial shocks on economic activity widely varies across LA6 and is otherwise found to be stronger in periods of financial stress. Fourth, exposure to regional financial spillovers also differs across LA6.
\end{abstract}

JEL classification: E17, E44, E5

Keywords: Financial conditions indexes, TVP-FAVAR, financial spillovers Authors' contact information: 1marques@imf.org, eperezruiz@imf.org 


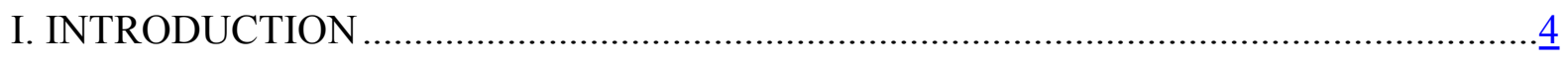

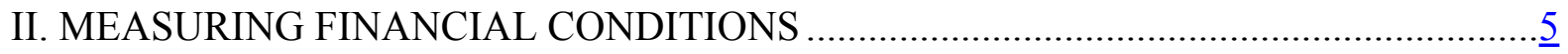

A. Variable Selection .................................................................................... $\frac{6}{7}$

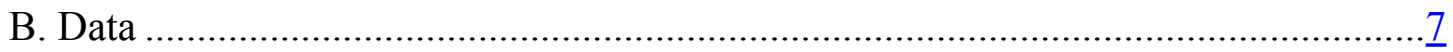

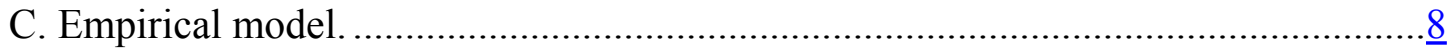

III. FINANCIAL CONDITIONS IN LA6 OVER THE PAST 15 YEARS ............................ $\underline{8}$

A. Characterizing Financial Conditions in LA6 ................................................... $\frac{8}{8}$

B. Impact of Financial Conditions on Activity ............................................... $\frac{15}{5}$

IV. REGIONAL FINANCIAL INTERCONNECTEDNESS...........................................

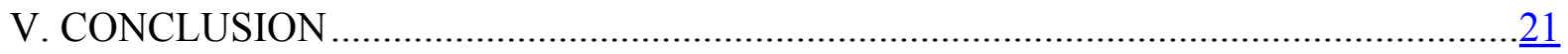

\section{TABLES}

1. Variables in FCI by Country ..................................................................................

2. Correlations between Latent Factors and Country-Specific FCIs ...................................12

\section{FiguRES}

1. LA6 Financial Conditions ............................................................................................. 9

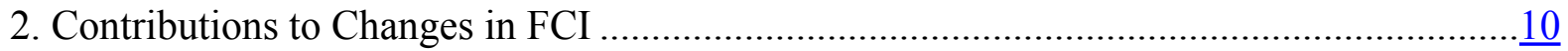

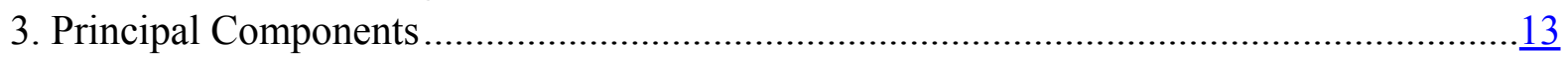

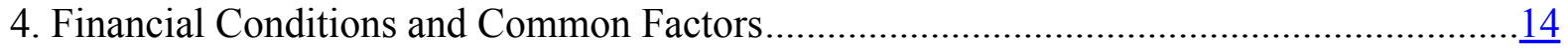

5. Impact of Financial Conditions on Macroeconomic ActivityError! Bookmark not defined.

6. Financial Spillovers Among LA6 Countries.......................................................... 20

\section{APPENDIXES}

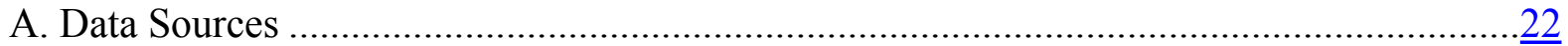

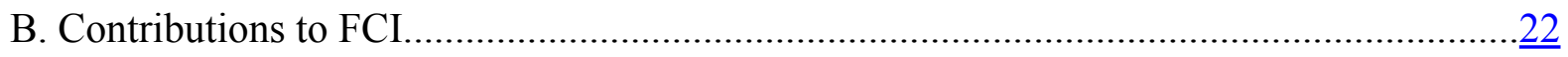

C. Time-Varying Loadings and Contributions ..........................................................

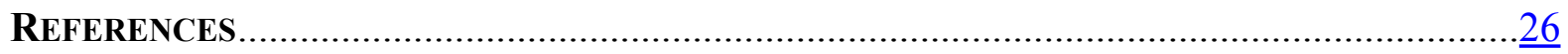




\section{INTRODUCTION ${ }^{1}$}

The rise in financial market integration, the global financial crisis, and the recent strengthening of the dollar and changing market sentiment, have all exposed the importance of financial factors in explaining activity and spillovers across countries (GFSR, April 2016). This development has sparked interest in the accurate measurement of financial conditions, their impact on economic activity, and their role in transmitting shocks. Although the relevance of financial conditions is broad, their role as driver and amplifier of business cycles is particularly important for Latin America, given the significance of capital flows and commodities cycles in the region.

This paper develops financial conditions indices (FCIs) for the six large and most financiallyintegrated Latin American economies (LA6 ${ }^{2}$ ) which are comparable across countries. By financial conditions we mean exogenous changes in financial markets as opposed to changes in financial conditions that reflect the evolution of the business cycle or monetary policy decisions. For example, the former could include unanticipated shifts in investors' preference for liquidity or shocks to the net worth of borrowers.

Based on these FCIs, we achieve three things. First, we use the estimated FCIs to characterize financial conditions and underlying common drivers in the region. ${ }^{3}$ Second, we investigate the impact of financial conditions on economic activity and whether this relationship changes over time. Third, we use the estimated FCIs to characterize financial spillovers within the region.

The main findings are as follows. The estimated FCIs are influenced by a commodity cycle and a global financial cycle, as well as country-specific episodes of financial distress. As of February 2017, financial conditions are estimated to remain favorable in most LA6 countries. Our findings also suggest that there is a significant reaction of output to financial sector developments in LA6, with a one standard deviation tightening of financial conditions lowering half-year ahead GDP growth by about $0.05-0.3$ percentage points depending on the country. We also find evidence of significant financial spillovers within the region.

In the literature, several methodologies for constructing FCIs have been proposed, from simple weighted averages of financial variables through more sophisticated econometric techniques (see, , Hatzius and others, 2010, Braves and Butters, 2011, Matheson, 2011, Akarli and others, 2012). We follow a Time-Varying Parameter Factor-Augmented Vector Autoregression (TVPFAVAR) approach to estimate financial conditions (see Koop and Korobilis, 2014, and references therein). This methodology has three main advantages. First, given the complex

\footnotetext{
${ }^{1}$ We are grateful to Adrian Alter, Carlos Caceres, Stephan Danninger, Inci Otker, Fabian Lipinsky for valuable comments. We are indebted to Carlos Goes, Daniela Muhaj, Adrian Robles, Jose Luis Saboin, Genevieve Lindow, Martin Sasson, and Ehab Tawfik for excellent research assistance.

${ }^{2}$ LA6 includes Argentina, Brazil, Chile, Colombia, Mexico, and Peru.

${ }^{3}$ The estimated FCIs measure is, at each point in time, the financial gap relative to historical standards. The data are normalized such that a FCI value of zero corresponds to a financial system operating at the historical average level of financial conditions
} 
nature of macro-financial linkages the method relies on a large set of financial variables, the loadings of which reflect the importance of each financial variable to fluctuations in the broader financial system and macroeconomic conditions. Second, since the FCIs are meant to capture exogenous shifts in financial conditions, the method adjusts for the effects of the business cycle, monetary policy, and exchange rate movements, which also affect financial conditions but originate outside the financial sector. Third, the method allows for a time-varying intensity in the transmission of financial conditions to economic activity. Therefore, it can account for the evolving relationships between the macroeconomic and financial variables over time, including those that are not explicitly accounted for in the model.

Section II describes the data and discusses the methodology used to construct FCIs for LA6 countries. Section III characterizes financial conditions in LA6 over the past 15 years and underlying common drivers, and discusses the impact of financial conditions on economic activity. Section IV estimates and discusses financial spillovers within the region. Section V concludes.

\section{Measuring Financial Conditions}

The construction of FCIs involves the selection of financial variables to enter the FCI, the weights (loadings) used to average these financial variables into the index, and the relationship between the FCI and the macro-economy. There is good reason to think these may change over time, with much econometric evidence in favor of structural instabilities in the coefficients of macroeconomic and financial factor models (Sims, Stock, and Watson 1993, Cogley and Sargent 2001 and Primiceri 2005, for instance). As financial systems evolve, the variables that are most relevant for tracking financial conditions may change; and financial shocks can be expected to have a stronger transmission to macroeconomic variables in periods of financial stress (see, for example, Galvao and Owyang, 2014).

To characterize financial conditions in LA6 countries, we combine information from a wide range of financial variables into a single FCI indicator and use the approach proposed by Korobilis (2013) and Koop and Korobilis (2014; K\&K hereafter). K\&K's econometric approach combines the estimation of Primiceri's (2005) time-varying parameter vector-autoregression (TVP-VAR) with recent developments in factor analysis for large data sets (factor-augmented VARs or FAVARs, see Doz, Giannone, and Reichlin, 2011). ${ }^{4}$ FAVARs jointly model a large number of financial variables (used the construct the latent FCI) with key macroeconomic variables. ${ }^{5}$ In short, the TVP-FAVAR method's distinctive features are as follows:

1. Broad array of financial variables. Since no single variable fully captures financial conditions, $K \& \mathrm{~K}$ constructs FCIs from a broad set of financial indicators that

\footnotetext{
${ }^{4}$ The FCI is estimated using Koop and Korobilis' 2014 code, which was downloaded from Dimitris Korobilis' webpage (https://sites.google.com/site/dimitriskorobilis/matlab).

${ }^{5}$ The method relies on the Kalman filter and smoother and is simulation-free.
} 
captures the main channels through which financial conditions affect economic activitycredit conditions, leverage and quality of collateral, and intensity of perceived risk (see below and Table 1).

2. Changing weights. Since financial conditions may transmit to the real economy with varying intensity, the approach allows for different financial variables to affect the estimation of the FCI with varying (or zero, when not selected) loadings in each period. TVP-VARs have enjoyed increasing popularity for forecasting macroeconomic variables since time-variation of parameters is found to improve the short-run forecasting performance against constant-parameter FAVAR alternatives (K\&K, 2014, page 110 and following).

3. Isolating financial shocks. The method aims to measure exogenous financial shocks, hence purges FCI variables of developments that influence financial conditions but that originate outside the financial system, such as the business cycle, monetary policy, or exchange movements. That is, FCIs should reflect information solely associated with the financial sector, rather than reflecting feedback from general macroeconomic conditions. This widely-acknowledged practice in the literature reflects the idea that FCIs should capture, to the extent possible, pure unanticipated financial shocks such as investors' shifts in preferences towards liquidity and risk. While alternative legitimate measures, unpurged FCIs cannot tell the extent to which tight (loose) financial conditions are the endogenous result of macroeconomic conditions and/or monetary policy decisions versus autonomous changes in the financial environment.

\section{A. Variable Selection}

Given the complexity of the financial system, several financial variables are likely to be needed to characterize its multidimensional interactions with the real economic activity. Following the literature on the measurement of financial conditions (Brave and Butters, 2011 and 2012), the financial variables selected fall into broad three categories, which cover the main channels of transmission of financial conditions to the real economy:

i. Quantity developments, including loans by segment, domestic bond and equity issuance, and various measures of credit quality such as NPLs and expected probabilities of default for borrowers. Quantity developments measure the ease of access to finance which depend on the willingness to lend or borrow conditional on current market prices. When households and corporations cannot easily obtain credit or equity financing, consumption and investment may be negatively affected.

ii. Collateral and leverage variables, such as returns on stock indices, housing prices, priceto-earnings ratios, and capital-to-assets ratios. Collateral and leverage developments contain information on the quality of the balance sheets of both lenders and borrowers, thereby having on impact on the supply and demand of funds (Bernanke, Gertler, and Gilchrist 1999 and Gilchrist and Zakrajsek 2012). 
iii. Risk measures which cover mainly risk premiums (changes in CDS sovereign and EMBIG spreads, inter-bank, corporate, and term spreads) and volatility measures (equity returns and FX volatilities). Risk variables capture lenders' tolerance of risk towards certain market participants, thereby affecting the supply of funds.

Declining credit volumes and collateral, and widening spreads, lead to some tightening in financial conditions, and vice-versa.

\section{B. Data}

The LA6 FCIs are constructed using mostly monthly data from early 2000 until February 2017 (see Appendix A for sources of data). A few variables are available only quarterly and are converted to the monthly frequency using cubic spline interpolation. Cross-country overage is best for variables describing credit conditions but the length of coverage for each series varies considerably by country (Table 1). Each variable is transformed to achieve stationarity (if needed) following Brave and Butters (2011). Missing data are replaced with zeros.

\begin{tabular}{|c|c|c|c|c|c|c|c|c|}
\hline \multicolumn{9}{|c|}{ Table 1. Variables in FCI by Country } \\
\hline \multirow[t]{2}{*}{ Variables names 1/ } & \multirow[t]{2}{*}{ Transformation 2/ } & \multirow[t]{2}{*}{ Group 3/ } & \multirow[b]{2}{*}{ ARG } & \multirow[b]{2}{*}{ BRA } & \multicolumn{2}{|c|}{ Country } & \multirow[b]{2}{*}{ MEX } & \multirow[b]{2}{*}{ PER } \\
\hline & & & & & CHL & COL & & \\
\hline 1-Year EDF Banks (75th percentile) & LV & Credit & $\mathrm{x}$ & $\mathrm{x}$ & $\mathrm{x}$ & $\mathrm{x}$ & $\mathrm{x}$ & $\mathrm{x}$ \\
\hline 1-Year EDF Corporates (75th percentile) & LV & Credit & $x$ & $x$ & $x$ & $x$ & $x$ & $x$ \\
\hline Domestic bond issuance & LVMA & Credit & $x$ & $x$ & $x$ & & $x$ & \\
\hline Domestic equity issuance & LVMA & Credit & $x$ & $x$ & $x$ & & & \\
\hline$E L M I+L C$ & DLN & Credit & $x$ & $x$ & $x$ & $x$ & $x$ & $x$ \\
\hline Loans trade & DP12 & Credit & & & $x$ & & & $x$ \\
\hline Loans commercial & DP12 & Credit & $x$ & $x$ & $x$ & $x$ & $x$ & $x$ \\
\hline Loans commercial / Bank assets & DL12 & Credit & $x$ & $x$ & $x$ & $x$ & $x$ & $x$ \\
\hline Loans consumers & DP12 & Credit & $x$ & $x$ & $x$ & $x$ & $x$ & $x$ \\
\hline Loans consumers / Bank assets & DL12 & Credit & $x$ & $x$ & $\mathrm{x}$ & $x$ & $x$ & $x$ \\
\hline Loans housing & DP12 & Credit & $\mathrm{x}$ & $\mathrm{x}$ & $\mathrm{x}$ & $x$ & $\mathrm{x}$ & $x$ \\
\hline Loans housing / Bank assets & DL12 & Credit & $x$ & & $\mathrm{x}$ & $x$ & $x$ & $x$ \\
\hline Nonperforming loans to bank credit ratio & LV & Credit & $x$ & $x$ & $x$ & $x$ & $x$ & \\
\hline Total bank assets & LVMA & Credit & $\mathrm{x}$ & $\mathrm{x}$ & $\mathrm{x}$ & $\mathrm{x}$ & $\mathrm{x}$ & $\mathrm{x}$ \\
\hline Total loans to private sector & DP12 & Credit & $x$ & $x$ & $x$ & $x$ & $x$ & $x$ \\
\hline Trade loans / Bank assets & DL12 & Credit & & & $x$ & & & $x$ \\
\hline Capital to assets ratio & LV & Leverage & $\mathrm{x}$ & $x$ & $\mathrm{x}$ & $\mathrm{x}$ & $\mathrm{x}$ & \\
\hline Financial firms Datastream return index & DLN & Leverage & $x$ & $x$ & $x$ & $x$ & $x$ & $x$ \\
\hline Financials to Stock Total Market & LVMA & Leverage & $x$ & $x$ & $x$ & $x$ & $x$ & $x$ \\
\hline Housing prices & DLN & Leverage & $x$ & & $x$ & $x$ & $x$ & $x$ \\
\hline MMMF/Bond fund assets & LVMA & Leverage & $x$ & & $x$ & & & \\
\hline Pension fund assets (\% GDP) & DLN & Leverage & & $x$ & & & $x$ & $x$ \\
\hline Stock market general index & DLN & Leverage & $\mathrm{x}$ & $x$ & $\mathrm{x}$ & $x$ & $\mathrm{x}$ & $x$ \\
\hline Central bank rate-US T-Bill spread & $\mathrm{LV}$ & Risk & $x$ & $x$ & $x$ & $x$ & $x$ & $\mathrm{x}$ \\
\hline CDS Sovereign 2YR & LV & Risk & $x$ & $x$ & $x$ & $x$ & $x$ & $x$ \\
\hline EMBIG & LV & Risk & $x$ & $x$ & $x$ & $x$ & $x$ & $x$ \\
\hline FX Volatility & LV & Risk & $x$ & $x$ & $x$ & $x$ & $x$ & $x$ \\
\hline Interbank - MPR spread & LV & Risk & $x$ & $x$ & $x$ & $x$ & $x$ & $x$ \\
\hline Interest rates commercial loans - MPR spread & LV & Risk & $x$ & $x$ & $x$ & $x$ & $x$ & $x$ \\
\hline Interest rates consumer loans - MPR spread & LV & Risk & $x$ & & $x$ & $x$ & $x$ & $x$ \\
\hline Interest rates housing loans 3 years or more - MPR spread & LV & Risk & $\mathrm{x}$ & & $\mathrm{x}$ & $x$ & $x$ & $x$ \\
\hline Interest rates trade loans - US 3-Month T-bill rate spread & LV & Risk & & $x$ & $x$ & & & \\
\hline Net loan spread financial system, 30 to 89 days & DLV & Risk & $x$ & & $\mathrm{x}$ & $x$ & $x$ & $\mathrm{x}$ \\
\hline Net loan spread financial system, 90 days to 1 year & DLV & Risk & $x$ & $x$ & $x$ & $x$ & & $x$ \\
\hline Volatility of stock market general index & LV & Risk & $x$ & $x$ & $x$ & $x$ & $x$ & $x$ \\
\hline \multicolumn{9}{|c|}{$\begin{array}{l}\text { Sources: Banco Central de Brasil; Banco Central de Chile; Banco Central de Colombia; Banco Central de la República Argentina; Banco de México; Banco Central de Reserva del Perú; Bloomberg LP; Comisión } \\
\text { Nacional Bancaria y de Valores México; FactSet; Moody's CreditEdget; Superintendencia de Bancos e Instituciones Financieras de Chile; Superintendencia de Banca, Seguros y AFP del Perú; Superintendencia } \\
\text { de Valores y Seguros de Chile; Thomson-Reuters Datastream. }\end{array}$} \\
\hline \multicolumn{9}{|c|}{$\begin{array}{l}\text { 1/ CDS = Credit Default Spread; EDF = Expected Default Frequency; ELMI+LC = Emerging Local Markets Index, local-currency denominated; EMBIG = Emerging Market Bond Index Global; MMMF = Money Market } \\
\text { Mutual Fund; MPR = Monetary Policy Rate. }\end{array}$} \\
\hline \multicolumn{9}{|c|}{ 2/ Transformations: $D L=$ first difference; $D L N=$ first log-difference; DP12 = 12-month difference; $L V=$ level; $L V M A=$ ratio of level to 12 -month moving average. } \\
\hline $\begin{array}{l}\text { 3/ Credit: mainly quantity developments including loans, bonds a } \\
\text { appetite of lenders (borrowers). }\end{array}$ & eral/leverage: measure & 'ders' (borro & (1) & ce sheet & ; ri & & & ting risk \\
\hline
\end{tabular}




\section{Empirical model}

The empirical model is given by the following equation.

$$
\begin{aligned}
& X_{t}=\lambda_{t}^{y} Y_{t}+\lambda_{t}^{f} f_{t}+u_{t^{\prime}} \\
& {\left[\begin{array}{l}
Y_{t} \\
f_{t}
\end{array}\right]=B_{1, t}\left[\begin{array}{l}
Y_{t-1} \\
f_{t-1}
\end{array}\right]+B_{2, t}\left[\begin{array}{c}
Y_{t-2} \\
f_{t-2}
\end{array}\right]+\ldots+\varepsilon_{t}}
\end{aligned}
$$

in which $X$ is a vector of financial variables, $Y$ is a vector of macroeconomic variables (inflation, a monthly proxy for growth, the real effective exchange rate, and the monetary policy rate), $f$ is an unobservable (first) factor, and $\varepsilon$ and $u$ are uncorrelated (but heteroskedastic) error terms. In this setting, the factor $f$ is the financial conditions index and the coefficients $\lambda^{y}$ and $\lambda^{f}$ are the factor loadings which track the effect of both macroeconomic and financial conditions on each financial variable.

The first equation in (1) allows the extraction of a latent indicator of financial conditions, $f$, which is assumed to contain information that, after removing the effect of contemporaneous macroeconomic conditions, summarizes a large set of financial variables. The second equation models the dynamic relationship between financial and macroeconomic conditions and, subject to some identifying assumptions, allows us to quantify the effects of financial conditions on the macroeconomy and vice-versa. For tracking the effect of the FCI on GDP growth, in this paper, we use a Cholesky decomposition but different identification schemes can be easily accommodated.

The FCI is normalized to have a mean of zero and standard deviation of one over the observation period (2000-2016). Zero values signal historical average financial conditons and values above (below) zero indicate "tight" ("loose") conditions relative to the historical average, with increases (reductions) in the index signaling tighter (looser) financial conditions. Underlying the normalization of the data is the concept of "stationarity," or the notion that the mean and variance of each indicator do not vary over time. For this to be true, variables are first altered with a stationarity-inducing transformation prior to estimation. These transformations reported in Table 1.

\section{Financial Conditions in La6 Over the Past 15 Years}

\section{A. Characterizing Financial Conditions in LA6}

Financial conditions in LA6 are strongly influenced by major global events (Figure 1). The 2007-9 financial crisis represents the sharpest spike in financial conditions across the region since 2000 (barring Argentina), likely a reflection of capital account openness in these countries. The FCIs also track well other global episodes of financial tightening, albeit with varying intensities depending on the country. For instance, the European sovereign crisis (2011-12) and 
the taper tantrum episode of early 2013 were strongly felt in Brazil, Chile, and Peru. The impact of the U.S. elections on the estimated FCIs - once purged of foreign exchange rate and monetary policy rate movements - was muted by historical standards.

Figure 1. LA6 Financial Conditions

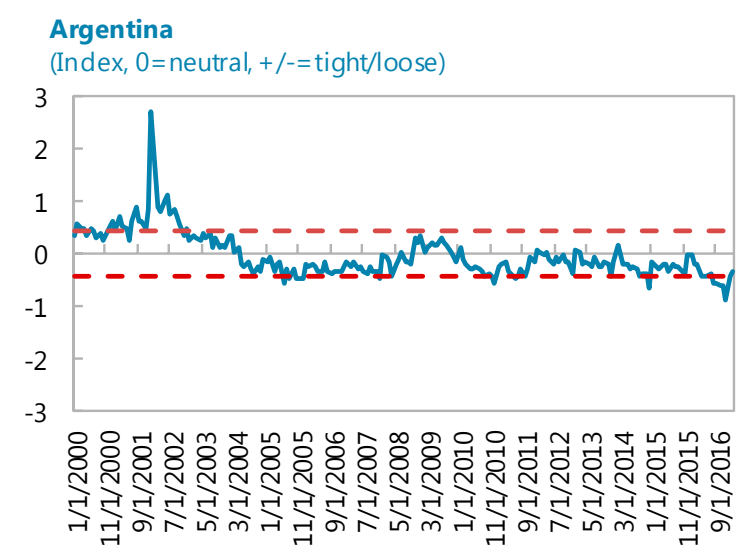

Brazil

(Index, $0=$ neutral,$+/$-=tight/loose)

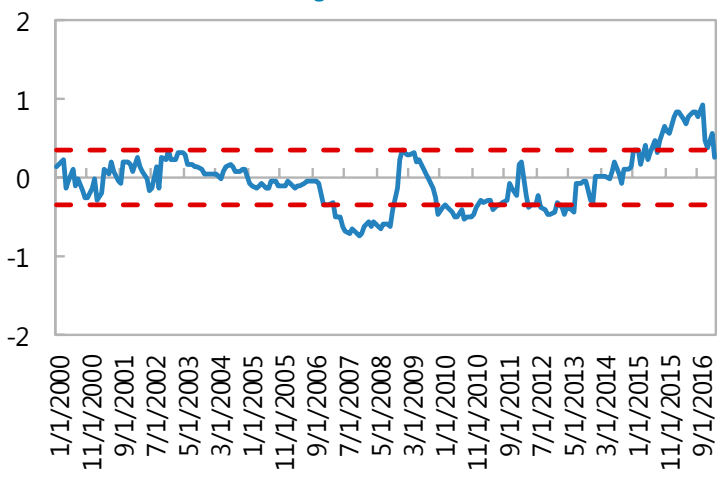

Chile

Colombia

(Index, $0=$ neutral, $+/$-=tight/loose)

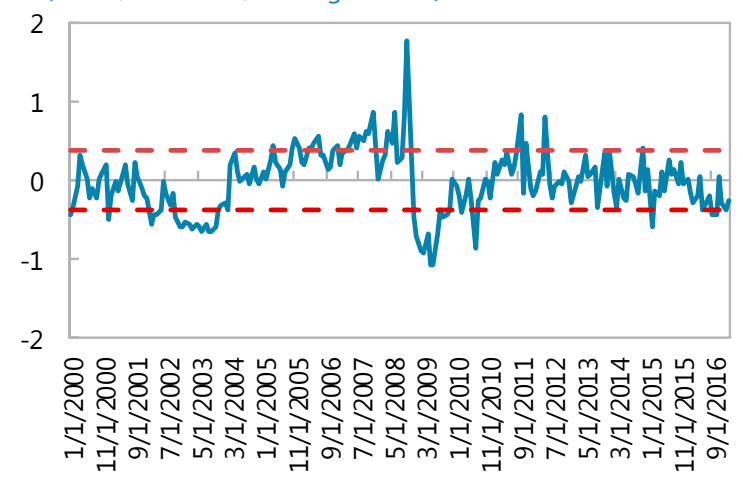

(Index, $0=$ neutral, + /-=tight/loose)

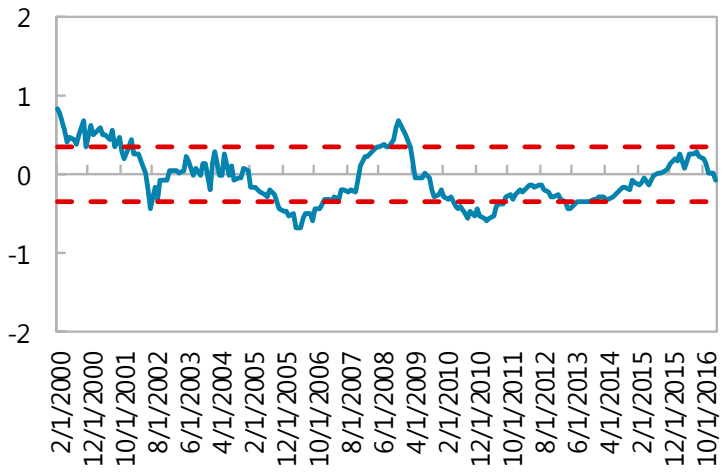

Mexico

Peru

(Index, $0=$ neutral, + /-=tight/loose)

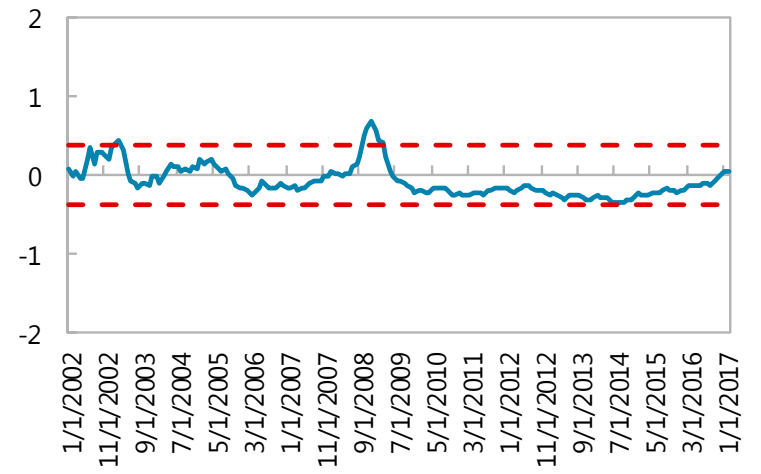

(Index, $0=$ neutral, $+/-=$ tight/loose)

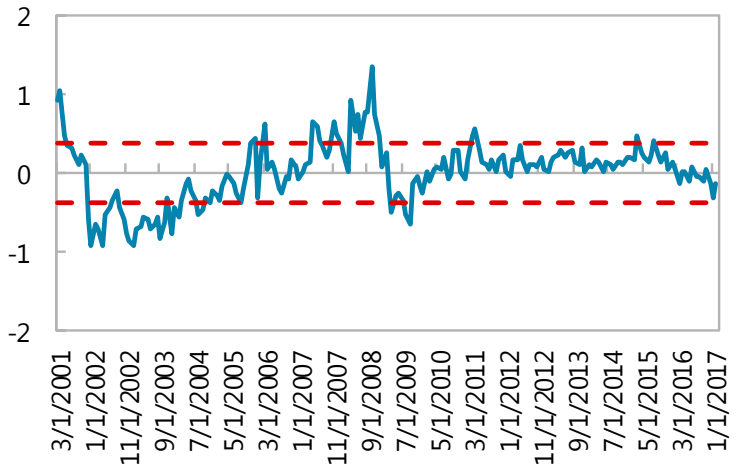

Sources: IMF staff.

Notes: The charts show, for all LAC6, TVP-FAVAR estimations of FCIs (bold blue line) and +/- one standard deviations (red dashed lines). Last data point is February 2017. 
The estimated FCIs seem to capture well country-specific periods of financial distress. Alongside major global events, domestic developments played, on occasion, an important role. These include the collapse of the Argentina currency board system and ensuing economic crisis; the tight credit conditions in the early 2000s in Colombia (following the mortgage crisis of the late 1990s); and, for Peru, the period of political uncertainty and economic slump of 2001.

Figure 2. Contributions to Changes in FCI
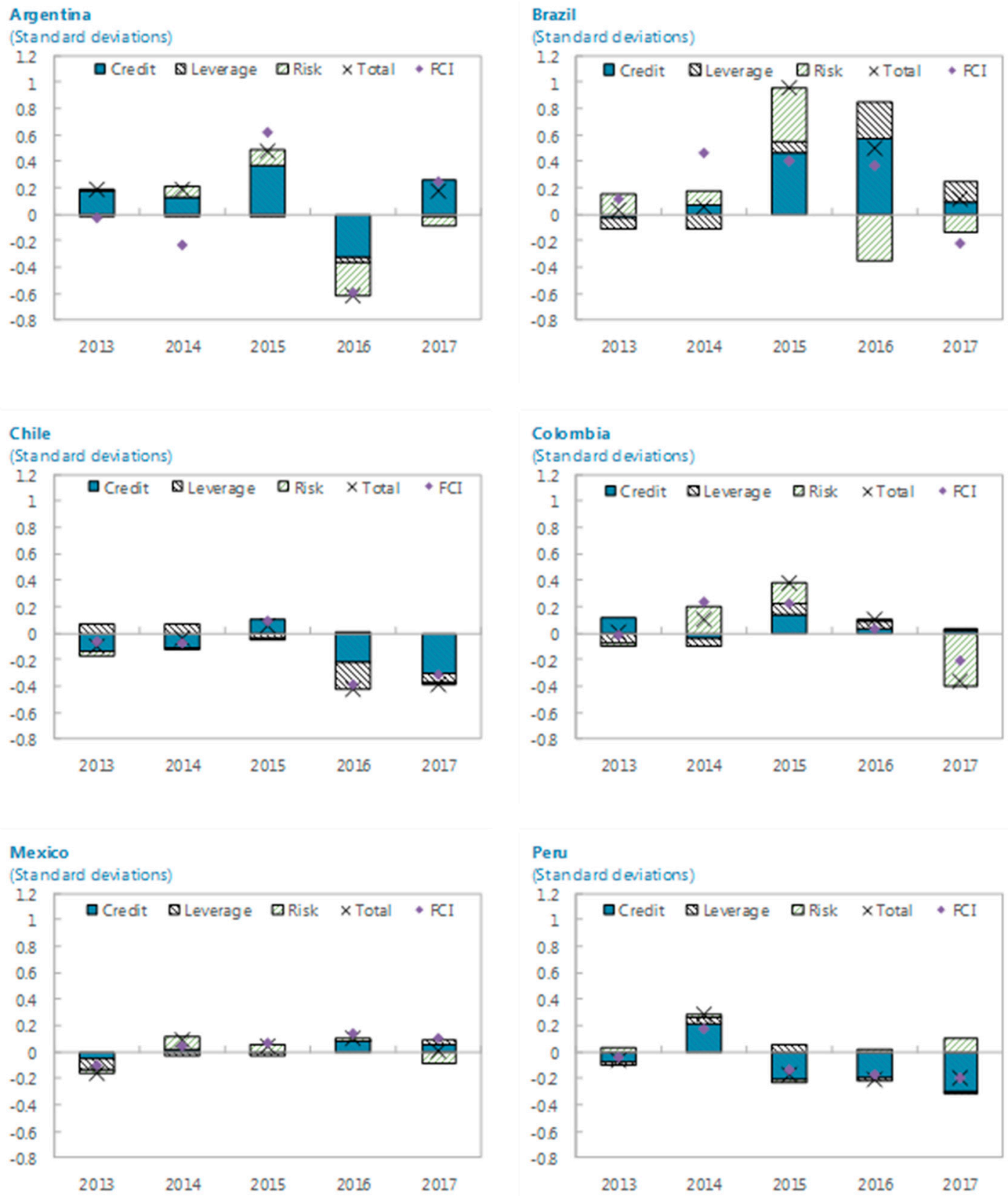

Source: IMF staff.

Note: 2016 = change from December 2015 to October 2015. 2017 = change from November 2016 to February 2017. All other years show December that year versus December in the previous year. The purple diamond shows the measured change in the FCI $\left(f_{t}\right)$. The black $x$-mark reflects the total contribution of credit, leverage and risk to financial conditions including the effects of the business cycle, monetary policy and exchange rate movements $X_{t}\left(1 / \lambda_{t}^{f}\right)$. 
The breakdown by contributing factors (see Appendix B for technical details) suggests that changes in credit and risk variables tend to dominate the FCI dynamics over changes in leverage and collateral variables. However, the specific FCI drivers vary across the countries considered. For instance, financial conditions throughout 2016 loosened in Argentina, Chile, and to a lesser extent Peru, tightened substantially in Brazil and more moderately in Mexico, and remained broadly unchanged in Colombia (Figure 2). Financial loosening was driven by easing credit and risk conditions in about equal proportions in Argentina (growing money market liquidity and commercial loans, and reduced stock market and FX volatility, respectively), increasing credit and financial firms' capital in Chile (growing bank assets and total loans to the private sector, and higher financial firms' valuation, respectively), and easing credit in Peru (growing bank assets and loans to the private sector). Tighter credit and declining collateral lead to a tightening of financial conditions in Brazil (declining total bank assets and loans to the private sector, increasing NPLs and declining financial firms' valuation). In Mexico, credit conditions deteriorated marginally (declining money market liquidity and loans to the private sector, particularly consumer loans).

Following some tightening after the elections in the United States, financial conditions eased back and remain relatively favorable (by historical standards) for most LA6 countries. As of February 2017, financial conditions looked loose in Argentina and Chile, broadly neutral in Colombia, Mexico, and Peru, and somewhat tight in Brazil.

Over 2013-17 changes in the FCIs in most countries are close to what would be warranted by cyclical macroeconomic conditions. There are, however, a few instances where financial conditions deteriorated more than warranted by cyclical conditions (Brazil and Colombia 2014, Argentina 2015); deteriorated less than warranted by cyclical conditions (Brazil 2015); or improved beyond what would be warranted by cyclical conditions (Argentina 2014, Brazil 2017).

Two common factors dominate the dynamics of financial conditions across the region (Table 1 and Figure 3 and Figure 4). Principal components analysis suggests that two latent factors summarize up to 70 percent of the variance structure of FCIs across the region. ${ }^{6}$ The first common factor (which accounts for about 43 percent of the variance) is highly correlated with world commodity prices. A second orthogonal component (explaining about 26 percent of the variance) is closely linked to the VIX (a barometer of investor sentiment), and as such, can be regarded as a proxy for a global financial cycle (GFSR, April 2017).

\footnotetext{
${ }^{6}$ We perform a principal components analysis of the six country FCIs. The first principal component, by definition, explains the largest share of the variance across FCIs. Then, we calculate the correlations of each component with the VIX and the IMF's world commodity price index.
} 
Table 2. Correlations between Latent Factors and Country-Specific FCls

\begin{tabular}{lrrrrrr}
\hline \hline & ARG & BRA & CHL & COL & MEX & PER \\
\cline { 2 - 7 } First principal component & 0.73 & 0.62 & -0.74 & 0.62 & 0.54 & -0.64 \\
Second principal component & 0.14 & -0.37 & 0.60 & 0.45 & 0.60 & 0.71 \\
\hline
\end{tabular}

Source: Staff.

Note: The correlation coefficient between the first principal component (43 percent of the total variance) and commodity prices is -0.73 . The correlation coefficient between the second principal component ( 26 percent of the variance) and the VIX is 0.38 .

The correlation of each country's FCI with the commodity-driven or the VIX-driven component probably reflects structural factors of each country's economy and financial system. On the one hand, the commodity price factor appears closely correlated with financial conditions in all countries in the region, with the highest correlation (in absolute value) with Chile and Argentina and lowest with Mexico. ${ }^{7}$ On the other hand, the global financial factor is strongly linked to financial conditions in Chile, Mexico and Peru - the countries with the highest level of financial integration with the rest of the world - and considerably less so with the FCIs of Argentina, Brazil, and Colombia (the least financially integrated in the sample). ${ }^{8}$

\footnotetext{
${ }^{7}$ An explanation of these correlations deserves further investigation.

${ }^{8}$ Peru, Chile, and Mexico had, in 2014, a Chinn-Ito index of financial openness of 1, 0.7, and 0.7, respectively, while Argentina, Brazil, and Colombia had an index of 0, 0.4, and 0.4 (see Chinn and Ito 2006).
} 
Figure 3. Principal Components

First Principal Component and Commodity Prices (Indexes)

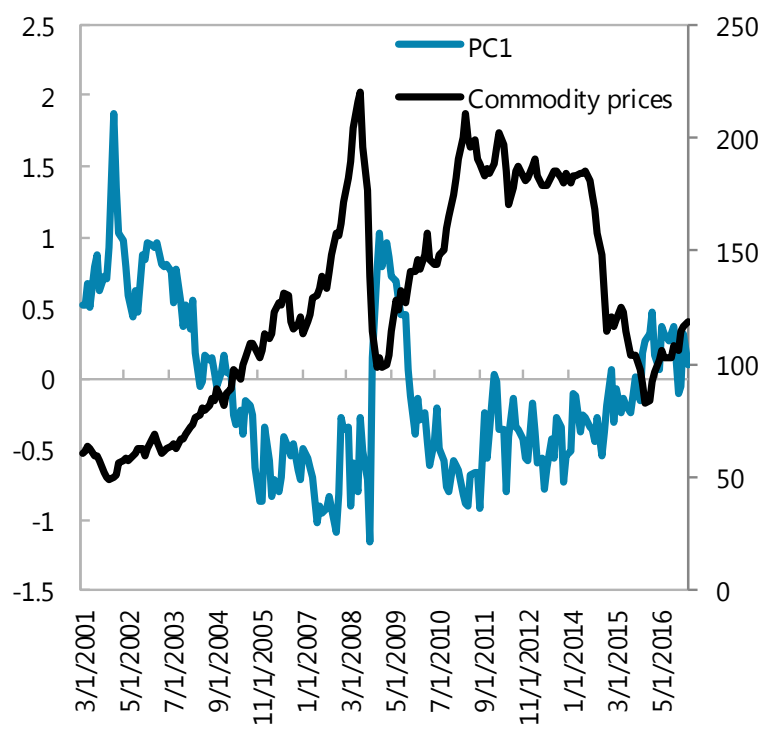

Second Principal Component and the VIX (Indexes)

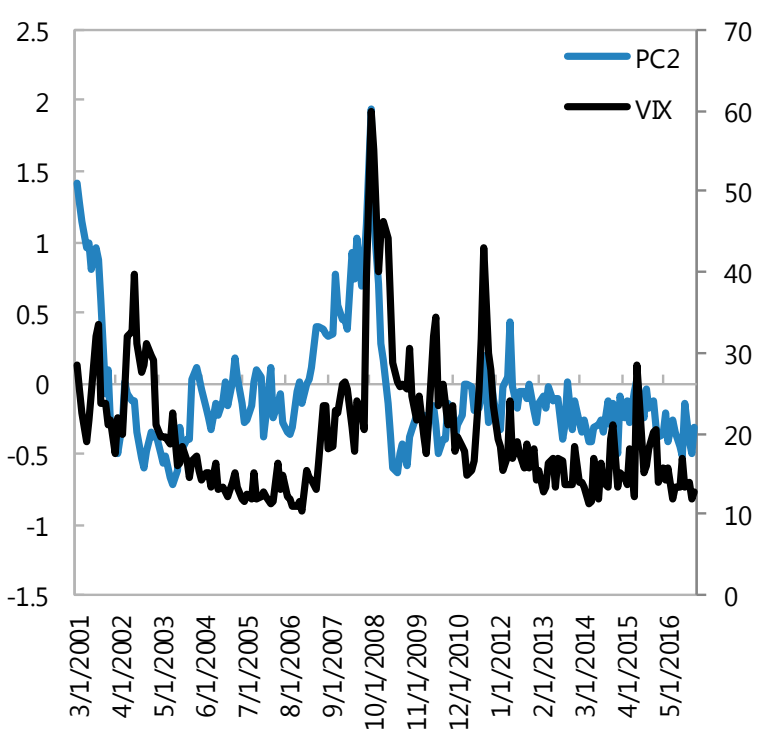

Source: IMF Staff.

Note: LHS chart plots the first principal component of all FCIs (43 percent of variance) against world commodity prices. RHS chart plots the second principal component of all FCIs (26 percent of variance) against the VIX. 
Figure 4. Financial Conditions and Common Factors

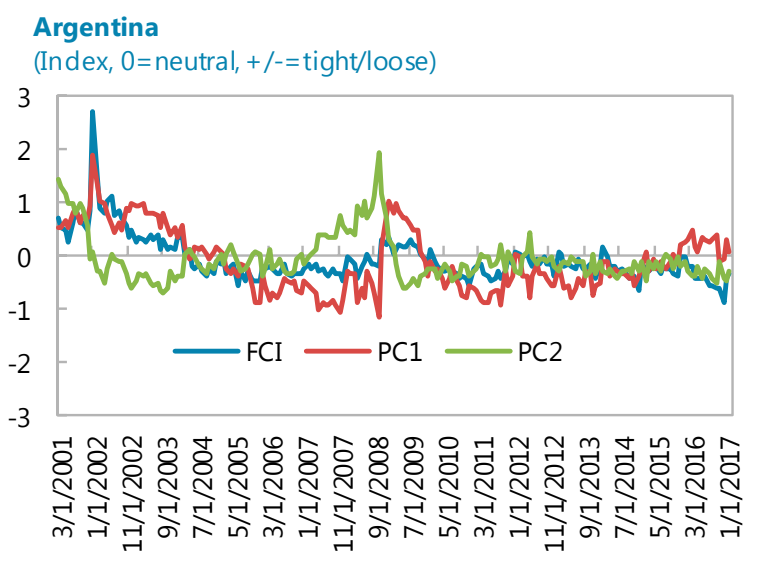

Brazil

(Index, $0=$ neutral, + /-=tight/loose)

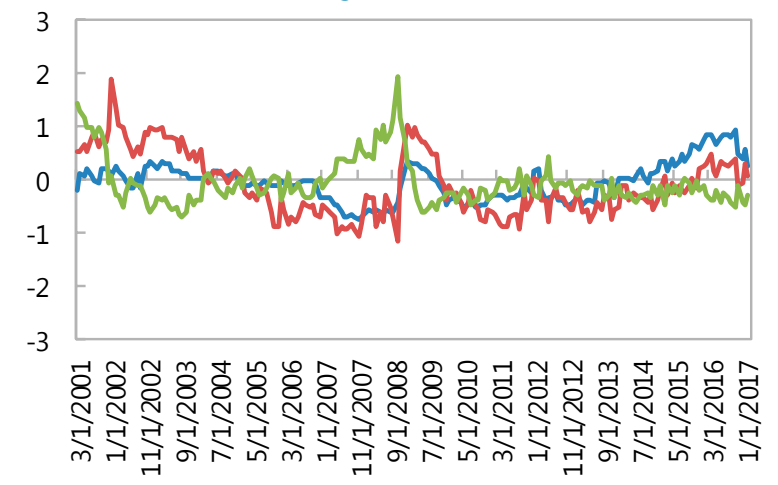

Chile

(Index, $0=$ neutral,$+/-=$ tight/loose)

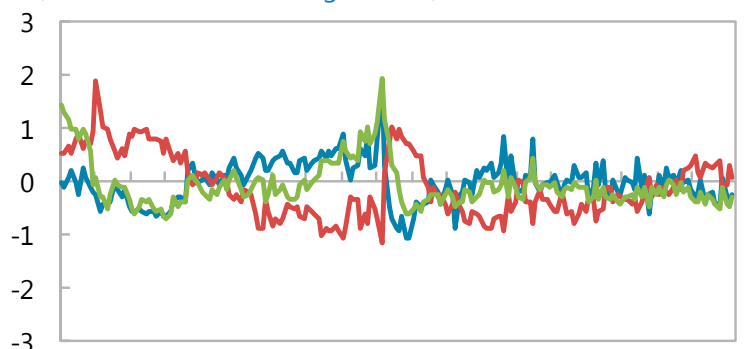

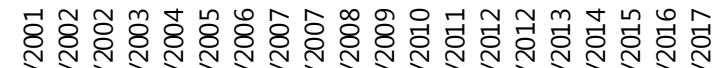

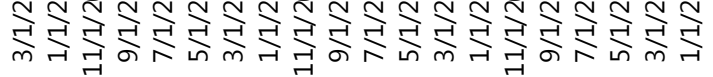

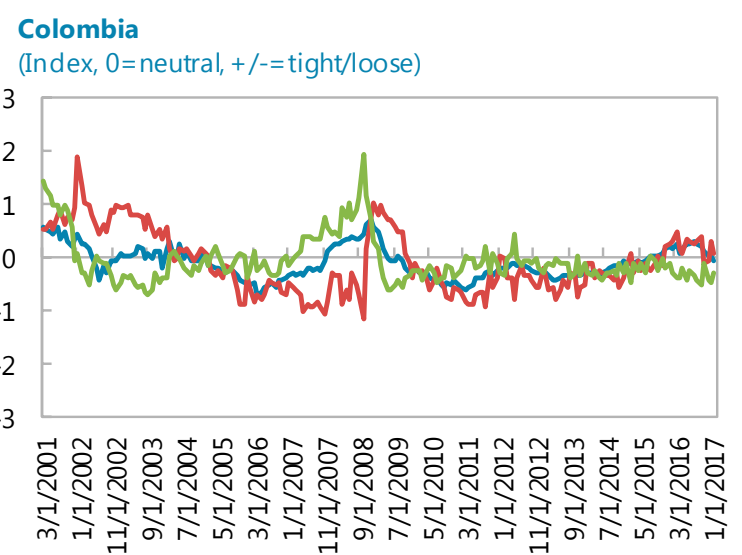

\section{Mexico}

(Index, $0=$ neutral, +/-=tight/loose)

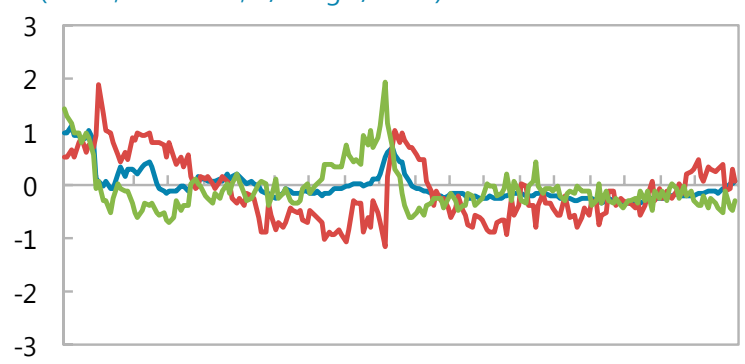

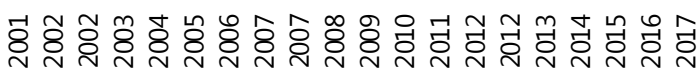

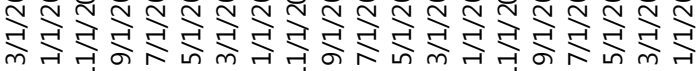

Peru

(Index, $0=$ neutral, +/-=tight/loose)

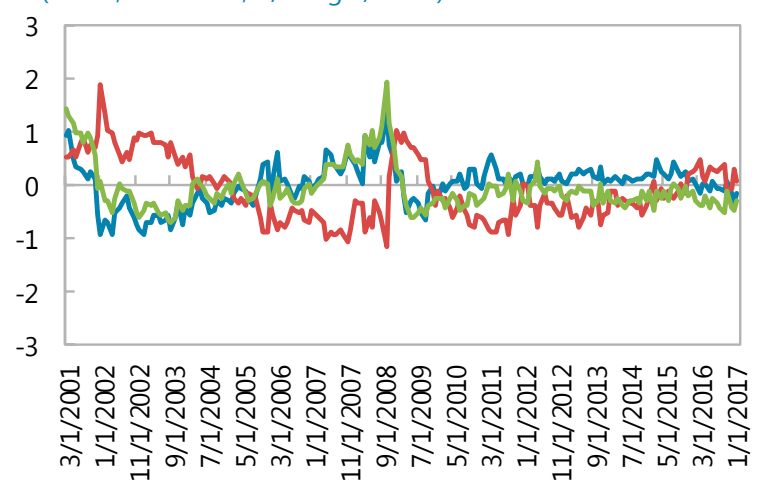

Source: IMF staff.

Note: The charts show the FCI for each country against the first two principal components for the six FCIs. Last data point is February 2017. 


\section{B. Impact of Financial Conditions on Activity}

We track the effect of orthogonal shocks to the FCI on GDP growth using a Cholesky decomposition and the following ordering: inflation, GDP growth, the REER, the monetary policy rate, and the FCI (see, for example, Adrian and Shin, 2008). For each month, we use the estimated time-varying VAR coefficients and factor loadings to build impulse response functions for GDP growth and other variables of interest.

The impact of financial shocks on economic activity varies dramatically across LA6. Using November 2016 loadings (Figure 5, dashed red line), a one standard deviation tightening of financial conditions is found to lower half-year-ahead GDP growth by between 0.05-0.1 percentage points (Mexico, Argentina, Chile, and Peru) and $0.25-0.3$ percentage points (Brazil, Colombia). Depending on the country, the trough in activity occurs between the fifth (Argentina and Chile) and tenth month (Colombia).

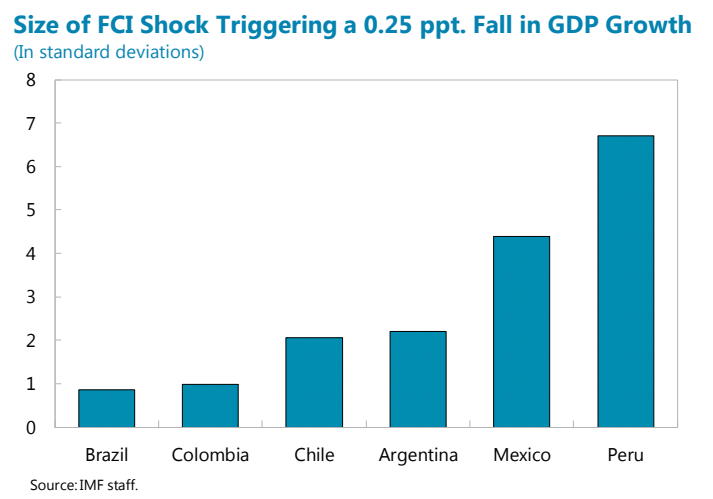
Put differently, a one standard deviation shock to the FCI suffices to generate a $1 / 4$ percentage point fall in GDP growth in Brazil and Colombia, but two standard deviations would be needed in Chile and Argentina (text chart). Activity in Mexico and Peru appears only slightly sensitive to changes in financial conditions, since around $4 \frac{1}{2}$ and $6 \frac{1}{2}$ standard deviation shocks to the FCI would be respectively needed to trigger $1 / 4$ percentage point fall in GDP growth.

The impact of financial shocks on economic activity can vary significantly over time (Error! Reference source not found., dashed red versus bold blue line). In periods of financial stress, such as during the 2007-9 financial crisis, in Argentina, Chile, and Mexico, the effect of financial tightening on economic activity is found to be between two and three times as high as in periods of more favorable financial conditions. ${ }^{9}$ This suggests that, during crisis periods, financial frictions become more important and financial variables have a stronger effect on economic activity.

\footnotetext{
${ }^{9}$ For instance, in Chile, the lost output after 24 months caused by a one-standard deviation FCI shock was 2.4 percent of GDP in October 2008 and 1.5 percent of GDP in November 2016.
} 


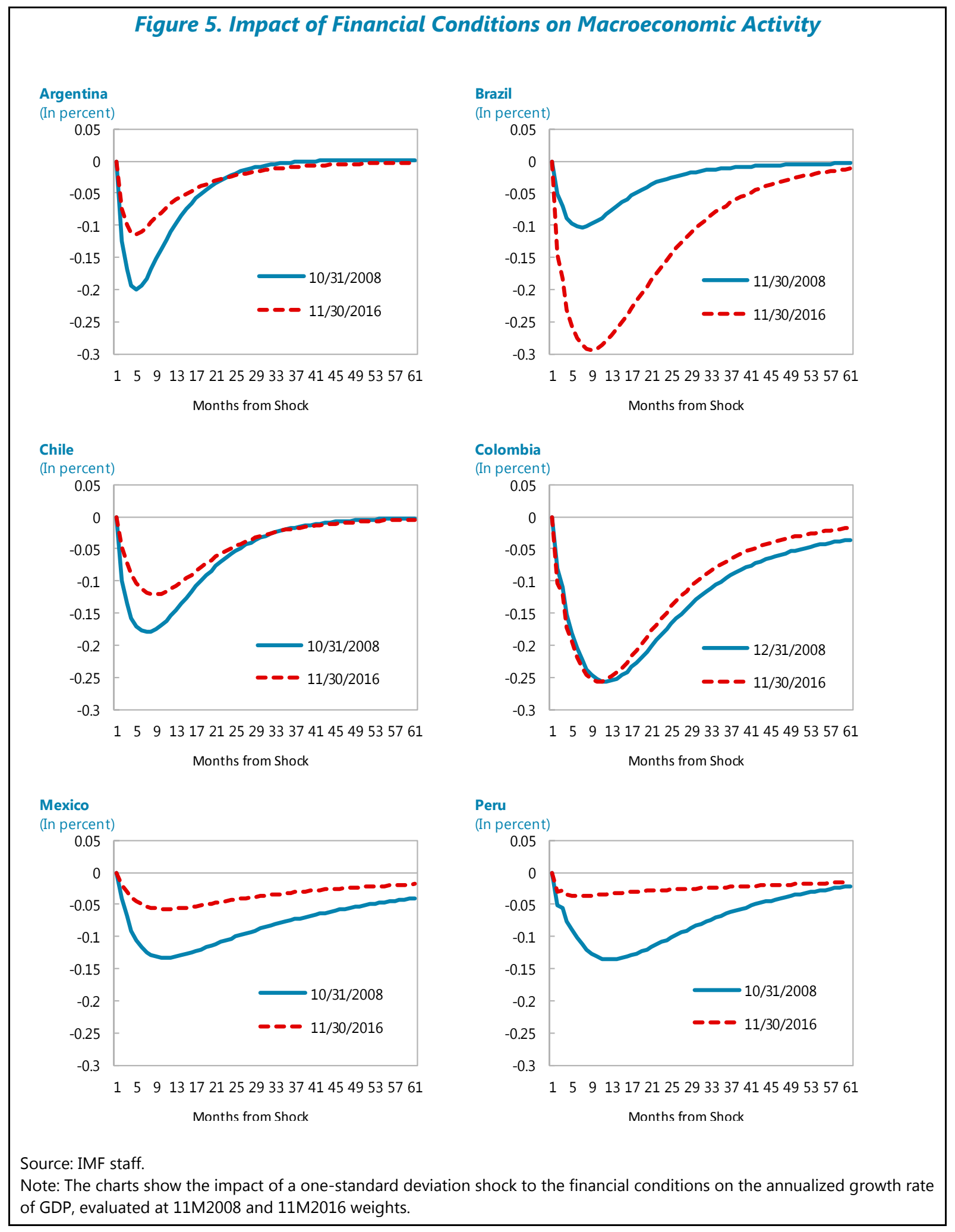




\section{Model Comparisons}

The model given by (1), in addition to the TVP-VAR FCI, has two other useful special cases in which the VAR parameters are not time-varying: (1) the principal components-based factoraugmented VAR (PCA-FAVAR) by Stock and Watson (2002) and Bernanke, Boivin, and Eliasz (2005); and (2) the Kalman-filter based factor-augmented VAR (KF-FAVAR) by Doz, Giannone, and Reichlin (2011). ${ }^{10}$

For LA6, the simpler alternatives (PCA-FAVAR and KF-FAVAR) closely track the more sophisticated TVP-FAVAR method (Figure 6). Furthermore, the contributions of each variable to the FCI are fairly stable over time. This suggests that the profile of the estimated FCIs is primarily driven by changes in the financial variables underlying its calculation rather than timevarying weights (see Appendix $\mathrm{C}$ for details). Although the broad patterns in the estimated FCIs are very similar to each other, the FCI produced by the TVP-FAVAR does differ from the other two in some instances. It is interesting to note that TVP-FAVAR at the end of the sample points to somewhat looser financial conditions in Argentina, Brazil, and slightly tighter financial conditions in Mexico, relative to alternatives. This indicates the potential importance of allowing for time variation in parameters. Another substantive divergence is for Colombia during the GFC, where the PCA- and KF-FAVAR alternatives point to a sharper deterioration in financial conditions. While small, these differences become relevant to forecast accuracy. In addition, TVP-FAVAR allows the measured effect of financial conditions on economic activity to change over time.

\footnotetext{
${ }^{10}$ See Koop and Korobilis (2014) for a discussion.
} 
Figure 6. Financial Conditions Indexes: Variants
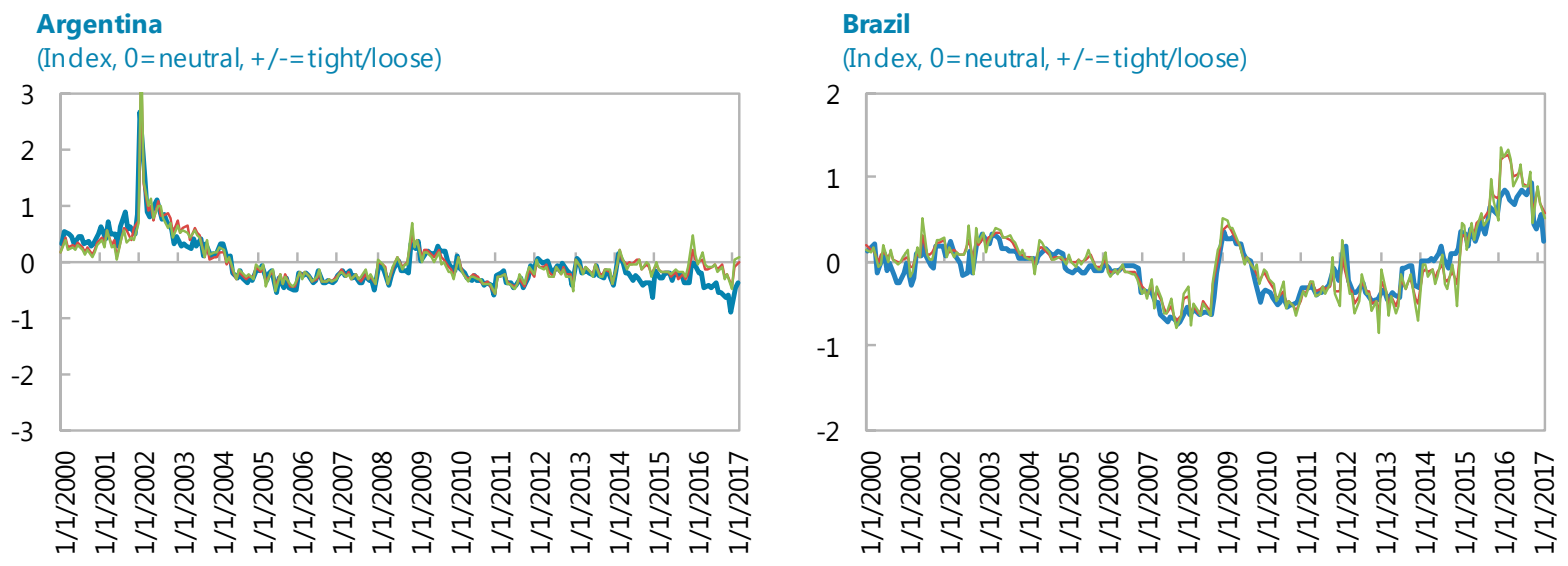

\section{Chile \\ (Index, $0=$ neutral, + /-=tight/loose)}

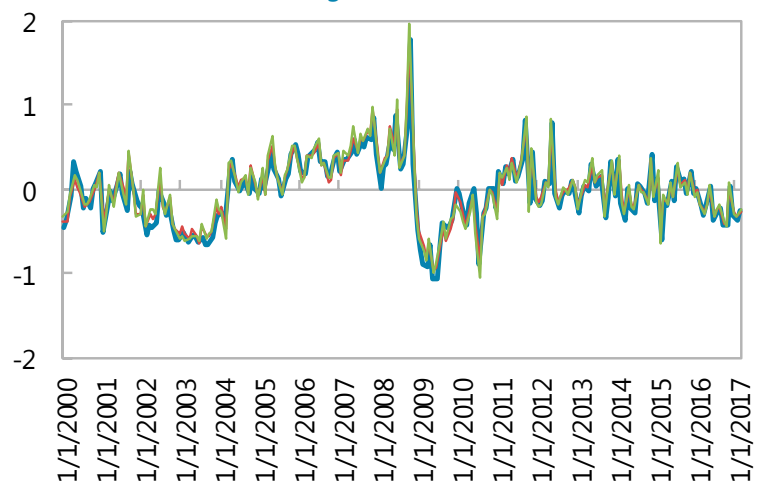

Mexico

(Index, $0=$ neutral,$+/-=$ tight/loose)

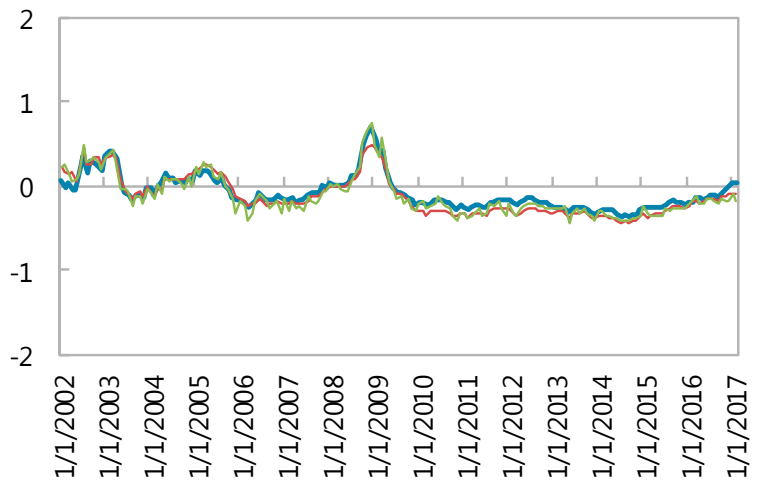

Colombia

(Index, $0=$ neutral, +/-=tight/loose)

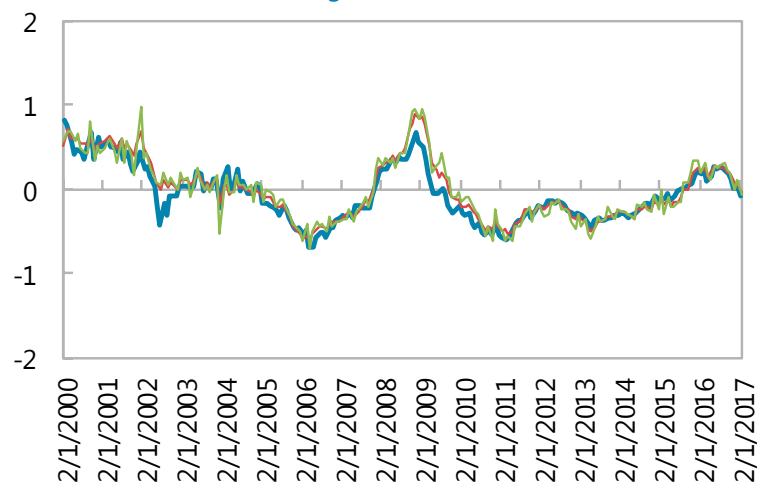

Peru

(Index, $0=$ neutral, + /-=tight/loose)

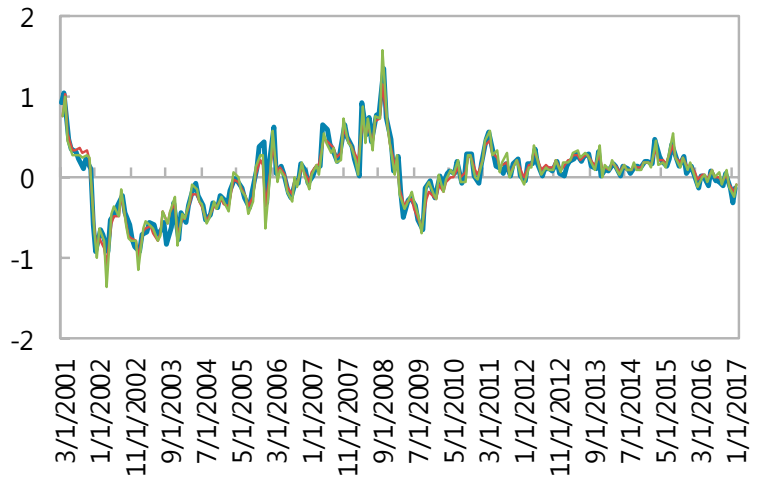

Source: IMF staff.

Note: The charts show, for all LA6, TVP-FAVAR-estimated FCIs (bold blue line), PC-FAVAR-estimated FCIs (bold green line), and KF-FAVAR-estimated FCIs (bold red line). Last data point is February 2017. 


\section{REgIONAL FinANCIAL INTERCONNECTEDNESS}

The rise of financial integration globally raises the question of how much financial conditions are driven by common global components versus domestic shocks. This section examines the importance of global, regional, and domestic shocks in shaping domestic financial conditions. Spillovers tend to occur more between countries with similar macro-financial fundamentals (GFSR, April 2016). In this section, we apply the Diebold and Yilmaz's (2014) spillovers framework to study regional financial connectedness in Latin America during the period $2014-16 .{ }^{11}$

A financial spillover from country A to country B is broadly defined as the share of the variation in country B's FCI shocks that can be attributed to (contemporaneous or preceding) shocks in country A's FCI shocks. The concept stresses truly idiosyncratic shocks and controls for comovement across markets that is driven by common factors.

To capture financial spillovers across LA6 countries we estimate a VAR of monthly FCIs incorporating global control variables to remove co-movement due to common factors. The specification is as follows:

$$
\begin{aligned}
& A(L) Y_{t}+B(L) X_{t}=\varepsilon_{t} \\
& D^{H} \equiv\left[d_{i, j}^{H}\right] \quad(2) \\
& X_{t}=[V I X, \ldots]_{t}
\end{aligned}
$$

in which $\mathrm{Y}$ is a vector of FCIs for the LA6 countries, $X$ uses world commodity prices and the Chicago Board Options Exchange Standard \& Poor's 500 Implied Volatility Index (VIX) to account for common global and regional factors, $A(L)$ is a lag polynomial with order chosen by the Bayesian Information Criterion (BIC), $B(L)$ is a vector of constants, and $\varepsilon$ is an error term. $d_{i, j}^{H}$ is the contribution of the FCI in country $j$ to the variance of the H-month ahead forecast error of the FCI in country $i$.

The VAR model above is used to build a generalized forecast-error variance decomposition (GVD), using Pesaran and Shin's (1998) methodology, to identify structural shocks to FCIs. ${ }^{12}$ The GVD for each FCI variable is further aggregated in a matrix, with the non-diagonal elements capturing spillovers effects. Specifically, the spillover from country $i$ to country $j$ is the percent of $j$ 's total inward spillovers that are coming from $i$ :

\footnotetext{
${ }^{11}$ The approach, which is part of a vibrant emerging literature using network perspectives in economic contexts, marries VAR-variance decomposition theory and network theory.

${ }^{12}$ The GVD identification framework is order invariant by construction, hence avoids the ad hoc ordering of structural shocks characteristic of recursive identification. However, the shocks are not necessarily uncorrelated.
} 


$$
s_{i j}=d_{i j} / \sum_{i \backslash\{j\}} d_{i j}
$$

The spillover therefore measures the fraction of the H-month ahead forecast error variance of country's $j$ FCI that can be accounted for by innovations in country's $i$ FCI. In this application, we focus on the 3-month ahead forecast error.

Figure 7. Financial Spillovers Among LA6 Countries

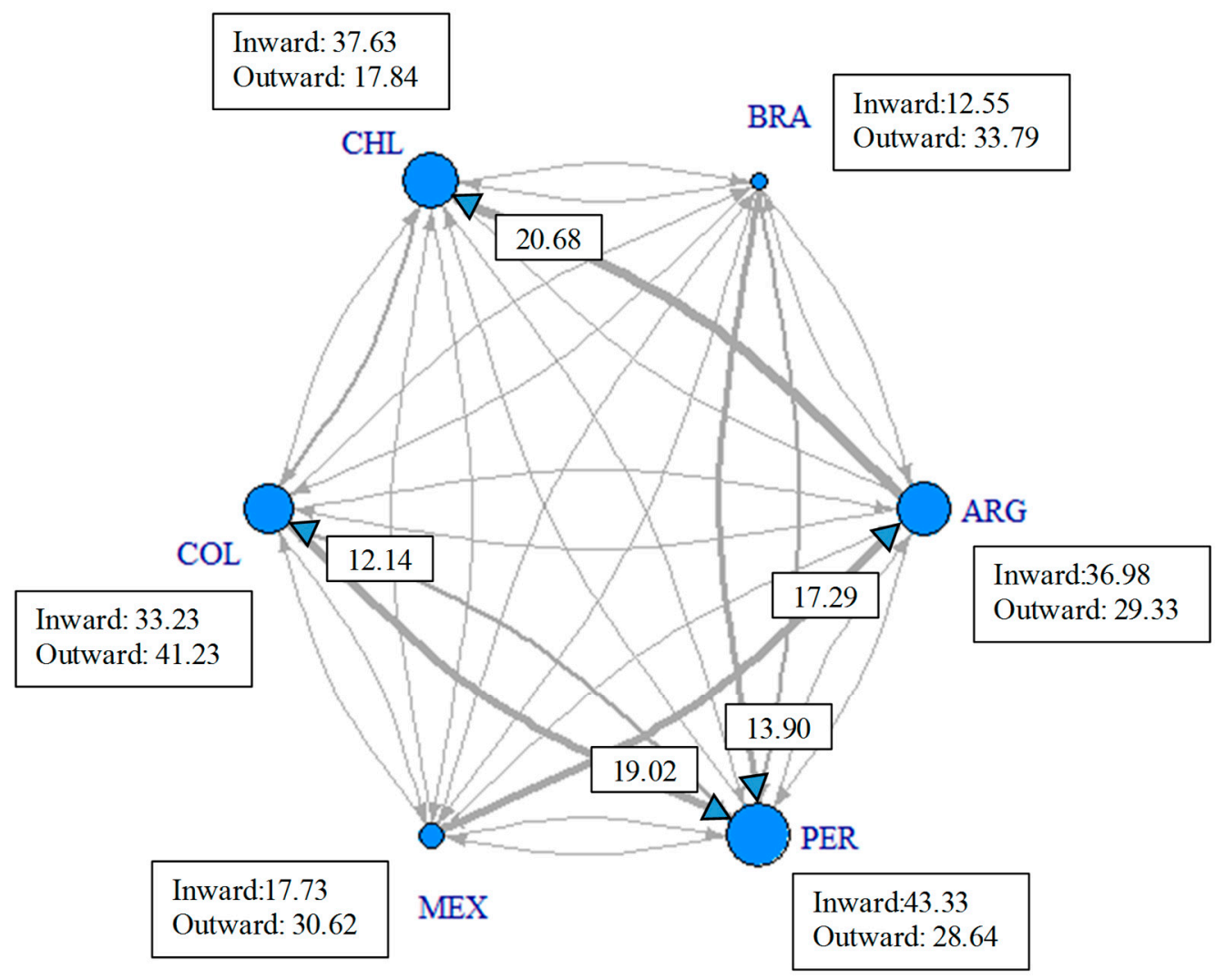

Sources: IMF staff.

Note: The chart shows financial spillovers to and from each country using Diebold and Yilmaz's (2014) approach. The size of the blue bubbles is proportional to the magnitude of total inward spillovers.

How strong are financial connections amongst LA6 countries? Over 2014-16 (Figure 7), the following stylized facts emerge:

- Domestic FCI shocks versus regional spillovers. Possibly reflecting their low degree of financial integration, shocks originating from the local financial sector explain the largest fraction of the variance decomposition of the FCI across LA6. This is particularly the case of the largest countries Brazil and Mexico (about 87 and 82 percent of the variance, respectively). In the remaining LA6 countries, shocks originating in the region explain between 33 percent (Colombia) and 43 percent (Peru) of the FCI variability. 
- Outward spillover potential. Brazil and Colombia display the largest spillover potential to other countries in the region, followed by Mexico, Argentina, and Peru. Chile transmitted comparatively smaller FCI spillovers to the region.

- Inward spillovers. ${ }^{13}$ Peru, Chile and Argentina show the strongest financial links with the other LA6 on the receiving end, followed by Colombia (the fraction of the variance decomposition of the volatility of each country's FCI explained by the rest of the region is about $44,38,37$, and 33 percent, respectively). Inward spillovers to the largest economies in the region, Brazil and Mexico, are comparatively smaller (about 13 and 18 percent, respectively).

- A few strong bilateral financial links stand out. Argentina is strongly affected by financial shocks in Mexico, Chile is significantly affected by financial conditions in Argentina, and there appears to be a financial feedback loop between Colombia and Peru.

\section{CONCLuSION}

This paper follows Korobilis (2013) and Koop and Korobilis (2014) to develop cross-country comparable financial conditions indices (FCIs) for the largest Latin American economies (LA6). The estimated FCIs are influenced by a commodity cycle and a global financial cycle, besides tracking well country-specific episodes of financial distress. By early 2017, financial conditions remained favorable in most LA6 countries relative to historical standards. Our findings also suggest that there is a significant reaction of output to financial sector developments in LA6, with a one standard deviation tightening of financial conditions lowering half-year ahead GDP growth by about 0.1 percentage points $(0.2-1 / 4$ percentage points in periods of financial stress). We also find evidence of significant financial spillovers within the region.

Going forward, it is important to improve our understanding of financial conditions in LA6 along three fronts. First, the underlying drivers of the correlation between global factors such as commodity prices or global risk appetite (VIX) should be explored, and each country's FCI deserve further investigation. In principle, the nature of each country's reliance on commodity exports or their degree of financial openness are likely candidates. Second, we need to understand better the reasons behind the time-varying nature of the response of GDP to FCI shocks. In particular, which financial frictions are important drivers of the changing transmission of financial shocks to the real economy? Third, the financial spillovers across the region warrant further scrutiny. Do they follow observed patterns of trade and cross-border investment flows?

\footnotetext{
${ }^{13}$ The expectation is that FCIs of countries that are more financially open display higher sensitivity to financial developments in the region. On the other hand, greater financial development (a larger domestic investor base, deeper banking systems and capital markets) and stronger institutional and policy frameworks should increase the resilience of local FCIs to regional financial shocks. Given that the FCIs are purged of macroeconomic drivers, real economic linkages, such as trade ties, should not help explain the influence of regional financial conditions.
} 


\section{Appendix A. Data Sources}

Here we present the sources of data used to construct the FCI for each LA6 economy (Table A.1).

\begin{tabular}{|c|c|c|c|c|c|c|c|c|}
\hline \multicolumn{9}{|c|}{ Table A.1. Data Sources } \\
\hline \multirow{2}{*}{ Variables names } & \multirow{2}{*}{ Transformation 1/ } & \multirow{2}{*}{ Group 2/ } & \multirow[b]{2}{*}{ ARG } & \multirow[b]{2}{*}{ BRA } & \multicolumn{2}{|l|}{ Country } & \multirow[b]{2}{*}{ MEX } & \multirow[b]{2}{*}{ PER } \\
\hline & & & & & CHL & COL & & \\
\hline 1-Year EDF Banks (75th percentile) & LV & Credit & CreditEdge + & CreditEdge+ & CreditEdge+ & CreditEdge+ & CreditEdge+ & CreditEdge+ \\
\hline 1-Year EDF Corporates (75th percentile) & LV & Credit & CreditEdge+ & CreditEdge+ & CreditEdge+ & CreditEdge+ & CreditEdge + & CreditEdge+ + \\
\hline Domestic bond issuance & LVMA & Credit & Dealogic & BCB & svs & & Banxico & \\
\hline Domestic equity issuance & LVMA & Credit & Dealogic & BCB & svs & & & \\
\hline ELMI + LC & DLN & Credit & Datastream & Datastream & Datastream & Datastream & Datastream & Datastream \\
\hline Loans trade & DP12 & Credit & & & Haver & & & Bloomberg \\
\hline Loans commercial & DP12 & Credit & Haver & Haver & Haver & Bloomberg & Haver & Bloomberg \\
\hline Loans commercial / Bank assets & DL12 & Credit & BCRA and Haver & $B C B$ and Haver & Haver and SBIF & Bloomberg & $\begin{array}{l}\text { Fin. Corporations } \\
\text { Survey and Haver }\end{array}$ & Bloomberg \\
\hline Loans consumers & DP12 & Credit & Haver & Haver & Haver & Bloomberg & Haver & Bloomberg \\
\hline Loans consumers / Bank assets & DL12 & Credit & BCRA and & BCB and Haver & Haver and SBIF & Bloomberg & $\begin{array}{l}\text { Fin. Corporations } \\
\text { Survey and Haver }\end{array}$ & Bloomberg \\
\hline Loans housing & DP12 & Credit & Haver & Haver & Haver & Bloomberg & Haver & Bloomberg \\
\hline Loans housing / Bank assets & DL12 & Credit & BCRA and & BCB and Haver & Haver and SBIF & Bloomberg & $\begin{array}{l}\text { Fin. Corporations } \\
\text { Survey and Haver }\end{array}$ & Bloomberg \\
\hline Nonperforming loans to bank credit ratio & LV & Credit & BCRA & $\mathrm{BCB}$ and $\mathrm{FSI}$ & $\mathrm{FSI}$ and SBIF & FSI & $\mathrm{FSI}$ & \\
\hline Total bank assets & LVMA & Credit & BCRA & BCB & SBIF & Bloomberg & $\begin{array}{l}\text { Financial } \\
\text { Corporations }\end{array}$ & Bloomberg \\
\hline $\begin{array}{l}\text { Total loans to private sector } \\
\text { Trade loans / Bank assets }\end{array}$ & $\begin{array}{l}\text { DP12 } \\
\text { DL12 }\end{array}$ & $\begin{array}{l}\text { Credit } \\
\text { Credit }\end{array}$ & Haver & Haver & $\begin{array}{l}\text { Haver } \\
\text { Haver and SBIF }\end{array}$ & Bloomberg & Haver & $\begin{array}{l}\text { Bloomberg } \\
\text { Bloomberg }\end{array}$ \\
\hline Capital to assets ratio & LV & Leverage & BCRA & BCB & SBIF & FSI & FSI & \\
\hline Financial firms Datastream return index & DLN & Leverage & Datastream & Datastream & Datastream & Datastream & Datastream & Datastream \\
\hline Financials to Stock Total Market & LVMA & Leverage & Datastream & Datastream & Datastream & Datastream & Datastream & Datastream \\
\hline Housing prices & DLN & Leverage & Haver & & Haver & Haver & Haver & Bloomberg \\
\hline MMMF/Bond fund assets & LVMA & Leverage & Haver & & svs & & & \\
\hline Pension fund assets (\% GDP) & DLN & Leverage & & Abrapp and Haver & & & Banxico & SBS and Haver \\
\hline Stock market general index & DLN & Leverage & Datastream & Datastream & Datastream & Datastream & Datastream & Haver \\
\hline Central bank rate-US T-Bill spread & LV & Risk & Haver & Haver & $\begin{array}{l}\text { Bloomberg and } \\
\text { Datastream }\end{array}$ & Haver & Haver & Haver \\
\hline CDS Sovereign $2 Y R$ & LV & Risk & Datastream & Datastream & Datastream & Datastream & Datastream & Datastream \\
\hline EMBIG & LV & Risk & Datastream & Datastream & Datastream & Datastream & Datastream & Datastream \\
\hline FXVolatility & LV & Risk & Datastream & Datastream & Datastream & Datastream & Datastream & Bloomberg \\
\hline Interbank - MPR spread & LV & Risk & BCRA & $\begin{array}{l}\text { Bloomberg and } \\
\text { Haver }\end{array}$ & Haver & $\begin{array}{l}\text { Bloomberg and } \\
\text { Datastream }\end{array}$ & $\begin{array}{l}\text { Datastream and } \\
\text { Haver }\end{array}$ & $\begin{array}{l}\text { Bloomberg and } \\
\text { Haver }\end{array}$ \\
\hline Interest rates commercial loans - MPR spread & LV & Risk & BCRA & BCB & Haver & $\begin{array}{l}\text { Bloomberg and } \\
\text { Haver }\end{array}$ & Haver & $\begin{array}{l}\text { BCRP and } \\
\text { Bloomberg }\end{array}$ \\
\hline Interest rates consumer loans - MPR spread & LV & Risk & BCRA & $\mathrm{BCB}$ & Haver & $\begin{array}{l}\text { Bloomberg and } \\
\text { Haver }\end{array}$ & Haver & $\begin{array}{l}\text { BCRP and } \\
\text { Bloomberg }\end{array}$ \\
\hline Interest rates housing loans 3 years or more - MPR spread & LV & Risk & BCRA & & Haver & $\begin{array}{l}\text { BanRep and } \\
\text { Bloomberg }\end{array}$ & Haver & $\begin{array}{l}\text { BCRP and } \\
\text { Bloomberg }\end{array}$ \\
\hline Interest rates trade loans - US 3-Month T-bill rate spread & LV & Risk & & & $\begin{array}{l}\text { Datastream and } \\
\text { Haver }\end{array}$ & & & \\
\hline Net loan spread financial system, 30 to 89 days & DLV & Risk & BCRA & & $\mathrm{BCCH}$ & IFS & IFS & Haver \\
\hline Net loan spread financial system, 90 days to 1 year & DLV & Risk & BCRA and Haver & ВСв & $\mathrm{BCCH}$ & BanRep & & Haver \\
\hline Volatility of stock market general index & LV & Risk & Datastream & Datastream & Datastream & Datastream & Datastream & Datastream \\
\hline 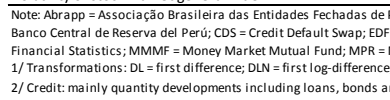 & . & 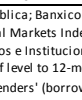 & senos & 年 & $\begin{array}{ll}\text { gg anarkek Bor } \\
\text { a, Seguros y }\end{array}$ & $\begin{array}{l}\text { tral de Chile; BCR } \\
\text { G Global; FSI = Fin } \\
=\text { = Superintenden }\end{array}$ & $\begin{array}{l}\text { nco Central de la R } \\
\text { Soundness Indica } \\
\text { Valores y Seguros. }\end{array}$ & $\begin{array}{l}\text { blica Argentina; } \\
\text {; IFS = Internatio }\end{array}$ \\
\hline
\end{tabular}

\section{Appendix B. Contributions to FCI}

The FCI for each country summarizes information from variables grouped in three categories: risk, credit, and leverage. To retrieve the contribution of each group of variables to the change in the FCI over a period, we employ a linear projection method. First, we estimate the FCI using the system of equations (1). Then, we solved the first equation in (1) for the FCI $(f)$ using a linear projection. This yields $\mathrm{f}$ as a function of $X$ and $y$.

$$
f=\left(\hat{\lambda}_{f}^{\prime} \hat{\lambda}_{f}\right)^{-1} \hat{\lambda}_{f}^{\prime}\left(x-\hat{\lambda}_{y} y\right)
$$

in which the $k$-th element of $\left(\hat{\lambda}_{f}^{\prime} \hat{\lambda}_{f}\right)^{-1} \hat{\lambda}_{f}^{\prime}$ yields the gross contribution of the $k$ th financial variable in $X$ to the FCI $f$ and $\left(\hat{\lambda}_{f}^{\prime} \hat{\lambda}_{f}\right)^{-1} \hat{\lambda}_{f}^{\prime} \hat{\lambda}_{y}$ the netting of the contribution of each macroeconomic variable in $y$ to the financial variables $\mathrm{X}$. That is, $\left(\hat{\lambda}_{f}^{\prime} \hat{\lambda}_{f}\right)^{-1} \hat{\lambda}_{f}^{\prime}$ yields the change in $\mathrm{f}$ that can be attributed to changes in the variables in $\mathrm{X}$ when the variables in $y$ do not change. The difference between the 
actual change in $f$ and the estimated contributions from $\left(\hat{\lambda}_{f}^{\prime} \hat{\lambda}_{f}\right)^{-1} \hat{\lambda}_{f}^{\prime} \Delta X$ is given by $\left(\hat{\lambda}_{f}^{\prime} \hat{\lambda}_{f}\right)^{-1} \hat{\lambda}_{f}^{\prime} \hat{\lambda}_{y} \Delta y$. This will typically happen when the macroeconomic conditions are above average.

\section{Appendix C. Time-Varying Loadings and Contributions}

An important feature of the TVP-FAVAR methodology is that it allows for loadings to change each period. This follows from previous literature showing time-variation in the loadings and covariances of factor models using financial and macroeconomic data (see Banerjee and others, 2008, and Koop and Korobilis, 2014). Time-varying weights allow for improved forecast accuracy of TVP-FAVARs relative to constant-parameter alternatives such as PC- and KFFAVARs. Following Appendix B, time-varying weights also mean the contribution (or score) of each variable to the FCI may vary over time. For an inspection of variability of variables' weights throughout the sample, see Table A.2.below. 


\begin{tabular}{|c|c|c|c|c|c|c|}
\hline \multicolumn{7}{|c|}{ Table A.2. Factor Loadings Volatility by Country } \\
\hline \multirow[t]{2}{*}{ Variable } & \multicolumn{6}{|c|}{ Country } \\
\hline & ARG & BRA & $\mathrm{CHL}$ & COL & MEX & PER \\
\hline 1-Year EDF Banks (75th percentile) & 0.000 & 0.017 & 0.001 & 0.001 & 0.000 & 0.000 \\
\hline 1-Year EDF Corporates (75th percentile) & 0.000 & 0.016 & 0.001 & 0.001 & 0.001 & 0.001 \\
\hline Domestic bond issuance & 0.000 & 0.014 & 0.004 & & 0.000 & \\
\hline Domestic equity issuance & 0.001 & 0.009 & 0.001 & & 0.000 & \\
\hline $\mathrm{ELMI}+\mathrm{LC}$ & 0.005 & 0.019 & 0.007 & 0.006 & 0.008 & 0.000 \\
\hline Loans trade & & & 0.002 & & 0.000 & 0.006 \\
\hline Loans commercial & 0.005 & 0.008 & 0.002 & 0.003 & 0.008 & 0.004 \\
\hline Loans commercial / Bank assets & 0.008 & 0.003 & 0.001 & 0.001 & 0.002 & 0.002 \\
\hline Loans consumers & 0.003 & 0.007 & 0.008 & 0.012 & 0.008 & 0.006 \\
\hline Loans consumers / Bank assets & 0.005 & 0.001 & 0.002 & 0.002 & 0.008 & 0.006 \\
\hline Loans housing & 0.001 & 0.000 & 0.002 & 0.004 & 0.012 & 0.003 \\
\hline Loans housing / Bank assets & 0.006 & & 0.002 & 0.003 & 0.001 & 0.001 \\
\hline Nonperforming loans to bank credit ratio & 0.002 & 0.025 & 0.004 & 0.006 & 0.003 & \\
\hline Total bank assets & 0.014 & 0.030 & 0.003 & 0.002 & 0.008 & 0.003 \\
\hline Total loans to private sector & 0.005 & 0.017 & 0.001 & 0.008 & 0.010 & 0.004 \\
\hline Trade loans / Bank assets & & & 0.002 & & 0.000 & 0.005 \\
\hline Capital to assets ratio & 0.001 & 0.031 & 0.004 & 0.003 & 0.001 & \\
\hline Financial firms Datastream return index & 0.002 & 0.019 & 0.004 & 0.004 & 0.006 & 0.004 \\
\hline Financials to Stock Total Market & 0.002 & 0.011 & 0.005 & 0.010 & 0.012 & 0.001 \\
\hline Housing prices & 0.003 & & 0.001 & 0.014 & 0.000 & 0.000 \\
\hline \multicolumn{7}{|l|}{ Long term external debt (\% GDP) } \\
\hline MMMF/Bond fund assets & 0.000 & & 0.001 & & 0.000 & \\
\hline Pension fund assets (\% GDP) & & 0.022 & 0.000 & & 0.003 & 0.001 \\
\hline \multicolumn{7}{|l|}{ Short term external debt (\% GDP) } \\
\hline Stock market general index & 0.004 & 0.024 & 0.003 & 0.007 & 0.008 & 0.003 \\
\hline Central bank rate-US T-Bill spread & 0.000 & 0.025 & 0.003 & 0.017 & 0.010 & 0.004 \\
\hline CDS Sovereign $2 Y R$ & 0.001 & 0.023 & 0.002 & 0.006 & 0.001 & 0.001 \\
\hline EMBIG & 0.006 & 0.085 & 0.011 & 0.034 & 0.021 & 0.009 \\
\hline FX Volatility & 0.008 & 0.009 & 0.005 & 0.003 & 0.002 & 0.000 \\
\hline Interbank - MPR spread & 0.004 & 0.018 & 0.015 & 0.004 & 0.003 & 0.006 \\
\hline Interest rates commercial loans - MPR spread & 0.004 & 0.000 & 0.002 & 0.004 & 0.005 & 0.008 \\
\hline Interest rates consumer loans - MPR spread & 0.008 & 0.001 & 0.003 & 0.003 & 0.006 & 0.005 \\
\hline Interest rates housing loans 3 years or more - MPR spread & 0.001 & 0.000 & 0.003 & 0.002 & 0.006 & 0.007 \\
\hline Interest rates trade loans - US 3-Month T-bill rate spread & & 0.000 & 0.002 & & 0.000 & \\
\hline Net loan spread financial system, 30 to 89 days & 0.004 & & 0.003 & 0.005 & 0.006 & 0.004 \\
\hline Net loan spread financial system, 90 days to 1 year & 0.004 & 0.000 & 0.002 & 0.002 & 0.000 & 0.002 \\
\hline Volatility of stock market general index & 0.003 & 0.006 & 0.002 & 0.004 & 0.003 & 0.002 \\
\hline
\end{tabular}

Furthermore, the rankings of variables by contribution for each country's FCI are fairly stable over time (see Table A.3). 


\begin{tabular}{|c|c|c|c|c|c|c|}
\hline \multicolumn{7}{|c|}{ Table A.3. Ranking of Contributions to FCI by Country } \\
\hline \multirow{2}{*}{\multicolumn{7}{|c|}{$\begin{array}{r}\text { Chile } \\
\text { October } 2008 \\
\end{array}$}} \\
\hline & & & & & & \\
\hline \multirow[t]{3}{*}{$\begin{array}{l}\text { Top } 3 \text { Positive Contributions } \\
\end{array}$} & $\begin{array}{l}\text { Total loans to private } \\
\text { sector }\end{array}$ & $\begin{array}{l}\text { Central bank rate-US T-Bill } \\
\text { spread }\end{array}$ & $\begin{array}{l}\text { Total loans to private } \\
\text { sector }\end{array}$ & $\begin{array}{l}\text { Total loans to private } \\
\text { sector }\end{array}$ & $\begin{array}{l}\text { Interest rates consumer } \\
\text { loans - MPR spread }\end{array}$ & $\begin{array}{l}\text { Total loans to private } \\
\text { sector }\end{array}$ \\
\hline & Loans commercial & EMBIG & Total bank assets & $\begin{array}{l}\text { Interest rates commercial } \\
\text { loans - MPR spread }\end{array}$ & $\begin{array}{l}\text { Interest rates commercial } \\
\text { loans - MPR spread }\end{array}$ & Loans commercial \\
\hline & $\begin{array}{l}\text { Loans commercial / Bank } \\
\text { assets }\end{array}$ & Stock market general index & Loans commercial & Loans housing & $\begin{array}{l}\text { Interest rates housing } \\
\text { loans } 3 \text { years or more - } \\
\text { MPR spread }\end{array}$ & Total bank assets \\
\hline \multirow[t]{3}{*}{ Top 3 Negative Contributions } & $E L M I+L C$ & Total bank assets & Capital to assets ratio & FX Volatility & $\mathrm{ELMl}+\mathrm{LC}$ & $\begin{array}{l}\text { Interest rates commercial } \\
\text { loans - MPR spread }\end{array}$ \\
\hline & $\begin{array}{l}\text { Interest rates commercial } \\
\text { loans - MPR spread }\end{array}$ & $\begin{array}{l}\text { Total loans to private } \\
\text { sector }\end{array}$ & $\begin{array}{l}\text { Loans housing / Bank } \\
\text { assets }\end{array}$ & $\begin{array}{l}\text { Central bank rate-US T-Bill } \\
\text { spread }\end{array}$ & $\begin{array}{l}\text { Central bank rate-US T-Bill } \\
\text { spread }\end{array}$ & $\begin{array}{l}\text { Interest rates consumer } \\
\text { loans - MPR spread }\end{array}$ \\
\hline & $\begin{array}{l}\text { Volatility of stock market } \\
\text { general index }\end{array}$ & Capital to assets ratio & $\begin{array}{l}\text { Loans consumers / Bank } \\
\text { assets }\end{array}$ & $\mathrm{ELMI}+\mathrm{LC}$ & EMBIG & Interbank - MPR spread \\
\hline \multicolumn{7}{|c|}{ November 2016} \\
\hline \multirow[t]{3}{*}{ Top 3 Positive Contributions } & $\begin{array}{l}\text { Total loans to private } \\
\text { sector }\end{array}$ & $\begin{array}{l}\text { Central bank rate-US T-Bill } \\
\text { spread }\end{array}$ & $\begin{array}{l}\text { Total loans to private } \\
\text { sector }\end{array}$ & $\begin{array}{l}\text { Total loans to private } \\
\text { sector }\end{array}$ & $\begin{array}{l}\text { Interest rates consumer } \\
\text { loans - MPR spread }\end{array}$ & $\begin{array}{l}\text { Total loans to private } \\
\text { sector }\end{array}$ \\
\hline & Loans commercial & EMBIG & Total bank assets & $\begin{array}{l}\text { Interest rates commercial } \\
\text { loans - MPR spread }\end{array}$ & $\begin{array}{l}\text { Interest rates housing } \\
\text { loans } 3 \text { years or more - } \\
\text { MPR spread }\end{array}$ & Loans commercial \\
\hline & $\begin{array}{l}\text { Loans commercial / Bank } \\
\text { assets }\end{array}$ & $\begin{array}{l}\text { Nonperforming loans to } \\
\text { bank credit ratio }\end{array}$ & Loans commercial & $\begin{array}{l}\text { Financials to Stock Total } \\
\text { Market }\end{array}$ & $\begin{array}{l}\text { Interest rates commercial } \\
\text { loans - MPR spread }\end{array}$ & Loans trade \\
\hline \multirow[t]{3}{*}{ Top 3 Negative Contributions } & $\mathrm{ELMI}+\mathrm{LC}$ & Total bank assets & Capital to assets ratio & EMBIG & EMBIG & $\begin{array}{l}\text { Loans consumers / Bank } \\
\text { assets }\end{array}$ \\
\hline & $\begin{array}{l}\text { Interest rates commercial } \\
\text { loans - MPR spread }\end{array}$ & $\begin{array}{l}\text { Total loans to private } \\
\text { sector }\end{array}$ & $\begin{array}{l}\text { Loans housing / Bank } \\
\text { assets }\end{array}$ & $\mathrm{ELMI}+\mathrm{LC}$ & $\begin{array}{l}\text { Central bank rate-US T-Bill } \\
\text { spread }\end{array}$ & $\begin{array}{l}\text { Interest rates housing } \\
\text { loans } 3 \text { years or more - } \\
\text { MPR spread }\end{array}$ \\
\hline & $\begin{array}{l}\text { Volatility of stock market } \\
\text { general index }\end{array}$ & Capital to assets ratio & $\begin{array}{l}\text { Loans consumers / Bank } \\
\text { assets }\end{array}$ & $\begin{array}{l}\text { Central bank rate-US T-Bill } \\
\text { spread }\end{array}$ & $E L M I+L C$ & $\begin{array}{l}\text { Interest rates commercial } \\
\text { loans - MPR spread }\end{array}$ \\
\hline
\end{tabular}




\section{REFERENCES}

Adrian T. and H. S. Shin, 2008, "Liquidity and leverage," Staff Reports 328, Federal Reserve Bank of New York.

Akarli, A., C. Grafe, M. Polan, K. Lund-Jensen, A. Matheny, and M. Hinds, 2012, "Recent financial Loosening Could Provide Upside to Growth," Goldman Sachs CEEMEA Economist Analyst, No. 12/03.

Banerjee, A., M., Marcellino, and I. Masten, 2008, "Forecasting macroeconomic variables using diffusion indexes in short samples with structural change," David Rapach and Mark Wohar, editors, Forecasting in the Presence of Structural Breaks and Model Uncertainty, Vol. 3: 149-194. Bingley, United Kingdom: Emerald Group Publishing Limited.

Bernanke, B.S., J. Boivin, and P. Eliasz, 2005, "Measuring the Effects of Monetary Policy: a Factor-Augmented Vector Autoregressive (FAVAR) Approach," Quarterly Journal of Economics 120, 387-422.

Bernanke, B. S., M. Gertler, and S. Gilchrist, 1999, "The financial accelerator in a quantitative business cycle framework," Handbook of Macroeconomics, 1999, vol. 1, Part C, pp $1341-1393$.

Brave, S. and A.R. Butters, 2011, "Monitoring financial stability: A financial conditions index approach," Economic Perspectives 1Q, Federal Reserve Bank of Chicago, pp. 22-43.

Brave, S. and A.R. Butters, 2012, "Diagnosing the Financial System: Financial Conditions and Financial Stress”, International Journal of Central Banking, June 2012.

Chinn, Menzie D. and Hiro Ito, 2006, “What Matters for Financial Development? Capital Controls, Institutions, and Interactions," Journal of Development Economics, Volume 81, Issue 1: 163-192.

Cogley T. and T. J. Sargent 2001, "Evolving Post-World War II U.S. Inflation Dynamics,” NBER Macroeconomics Annual, Cambridge, MA, MIT Press: 331-373.

Diebold, F. X. and K. Yilmaz, 2014, "On the network topology of variance decompositions: Measuring the connectedness of financial firms," Journal of Econometrics, Elsevier, vol. 182(1), pages 119-134.

Doz, C., D. Giannone, and L. Reichlin, 2011, “A two-step estimator for large approximate dynamic factor models based on Kalman filtering," Journal of Econometrics, Elsevier, vol. 164(1), pages 188-205, September. 
Galvao, A.B. and M.T. Owyang, 2014, "Financial Stress Regimes and the Macroeconomy," Federal Reserve Bank of St. Louis, Working Paper 2014-020C.

Gilchrist, S. and E. Zakrajsek, 2012, "Credit Spreads and Business Cycle Fluctuations," American Economic Review, vol. 102, no. 4, June 2012 (pp. 1692-1720).

Hatzius, J., P. Frederic, S. Mishkin, K. L. Schoenholtz, and M.W. Watson, 2010, "Financial Conditions Indexes: A Fresh Look after the Financial Crisis," NBER Working Paper No. 16150.

International Monetary Fund, 2016, Potent Policies for a Successful Normalization. Global Financial Stability Report April 2016, International Monetary Fund, Washington, D.C.

International Monetary Fund, 2017, “Are Countries Losing Control of Domestic Financial Conditions?" Global Financial Stability Report April 2017, Chapter 3. International Monetary Fund, Washington, D.C.

Korobilis, Dimitris, 2013, Assessing the Transmission of Monetary Policy Using Time-varying Parameter Dynamic Factor Models." Oxford Bulletin of Economics and Statistics 75, no. 2: $157-179$.

Koop, G. and D. Korobilis, 2014, “A new index of financial conditions," European Economic Review, 71, p. 101-116.

Matheson, T., 2011, "Financial Conditions Indexes for the United States and Euro Area," IMF WP 11/93.

Pesaran, M.H. and Y. Shin, 1998, "Generalized Impulse Response Analysis in Linear Multivariate Models," Economics Letters, 58, 17-29.

Primiceri, G. E., 2005, "Time Varying Structural Vector Autoregressions and Monetary Policy," The Review of Economic Studies, 72, 821-852.

Sims C. A., J. H. Stock, and M. W. Watson, 1993, “A 9 Variable Probabilistic Macroeconomic Forecasting Model," Business Cycles, Indicators and Forecasting, NBER Studies in Business Cycles, 1993, vol. 28: 179-214.

Stock, J. H, and M. W. Watson, 2002, "Forecasting Using Principal Components from a Large Number of Predictors," Journal of the American Statistical Association vol. 97, No. 460 (Dec., 2002), pp. 1167-1179. 